\title{
Technical Note: Characterisation of a DUALER instrument for the airborne measurement of peroxy radicals during AMMA 2006
}

\author{
D. Kartal ${ }^{1}$, M. D. Andrés-Hernández ${ }^{1}$, L. Reichert ${ }^{*}$, H. Schlager ${ }^{2}$, and J. P. Burrows ${ }^{1}$ \\ ${ }^{1}$ Institute of Environmental Physics, University of Bremen, Germany \\ ${ }^{2}$ Institute of Atmospheric Physics, German Aerospace Center (DLR), Oberpfaffenhofen, Germany \\ * formerly at: Institute of Environmental Physics, University of Bremen, Germany
}

Received: 24 July 2009 - Published in Atmos. Chem. Phys. Discuss.: 2 September 2009

Revised: 9 March 2010 - Accepted: 17 March 2010 - Published: 30 March 2010

\begin{abstract}
A DUALER (dual-channel airborne peroxy radical chemical amplifier) instrument has been developed and optimised for the airborne measurement of the total sum of peroxy radicals during the AMMA (African Monsoon Multidisciplinary Analyses) measurement campaign which took place in Burkina Faso in August 2006. The innovative feature of the instrument is that both reactors are sampling simultaneously from a common pre-reactor nozzle while the whole system is kept at a constant pressure to ensure more signal stability and accuracy.

Laboratory experiments were conducted to characterise the stability of the $\mathrm{NO}_{2}$ detector signal and the chain length with the pressure. The results show that airborne measurements using chemical amplification require constant pressure at the luminol detector. Wall losses of main peroxy radicals $\mathrm{HO}_{2}$ and $\mathrm{CH}_{3} \mathrm{O}_{2}$ were investigated. The chain length was experimentally determined for different ambient mixtures and compared with simulations performed by a chemical box model.

The DUALER instrument was successfully mounted within the German DLR-Falcon. The analysis of AMMA data utilises a validation procedure based on the $\mathrm{O}_{3}$ mixing ratios simultaneously measured onboard. The validation and analysis procedure is illustrated by means of the data measured during the AMMA campaign. The detection limit and the accuracy of the ambient measurements are also discussed.
\end{abstract}

Correspondence to:

M. D. Andrés-Hernández

(lola@iup.physik.uni-bremen.de)

\section{Introduction}

Hydroxyl- and alkyl-peroxy radicals, $\mathrm{HO}_{2}$ and $\mathrm{RO}_{2}$, where $\mathrm{R}$ stands for any organic chain, play an essential role in the chemistry of the troposphere, particularly in the formation and depletion mechanisms of ozone. In addition, they can be used as good indicators for the photochemical activity of the air masses. Radical chemistry in the troposphere has been subject of intensive research in the past 3 decades (Clemitshaw, 2004; Monks, 2005). As radicals are intermediates of many chemical reactions, it remains difficult to quantify their amount and impact in a particular environment. The peroxy radical concentration depends on complex photochemical mechanisms involving existing sources and sinks of nitrogen oxides $\left(\mathrm{NO}_{\mathrm{x}}=\mathrm{NO}+\mathrm{NO}_{2}\right)$, carbon monoxide $(\mathrm{CO})$, hydrocarbons and ozone $\left(\mathrm{O}_{3}\right)$. Consequently, there are still many unknowns both in clean and polluted atmospheres concerning radical formation and effect. Measurement data, especially scarce for high levels of the troposphere, are therefore required to improve the understanding of the tropospheric chemistry.

In recent years, both new detection techniques and substantial improvements in the characterisation of existing measurement techniques have been reported (Reiner et al., 1997; Cantrell et al., 1996, 2003a, b; Green et al., 2003, 2005; Mihele and Hastie, 1998; Mihele et al., 1999; Reichert et al., 2003). The quantitative and selective discrimination between $\mathrm{HO}_{2}$ and $\mathrm{RO}_{2}$ was first accomplished by the Matrix Isolation Spin Resonance Technique (Mihelcic et al., 1990). The field deployment of MIESR is however limited by its high weight, delicate sampling procedure and long sampling time. Most recent developments aim at the speciation of different peroxy radicals by using other techniques (Edwards et al., 2003; Fuchs et al., 2009).

Published by Copernicus Publications on behalf of the European Geosciences Union. 
The chemical amplification is one of the most frequently used measurement techniques for the determination of the total sum of peroxy radicals (PeRCA: Peroxy Radical Chemical Amplification). Since this technique was proposed by Cantrell and Stedman (1982) and calibrated by Hastie et al. (1991), there is abundant literature describing its gradual improvement and characterisation for the ambient measurement of peroxy radicals, and its deployment in diverse polluted and remote areas (e.g. Monks et al., 1996; Carslaw et al., 1999; Burkert et al., 2001a, b, 2003; Andrés-Hernández et al., 2001; Cantrell et al., 1996a; Volz-Thomas et al., 2003; Zanis et al., 2003; Fleming et al., 2006a, b).

In most cases, the measurement system consists of a single reactor and detector. However, for remote areas and airborne measurements, dual systems, comprising two identical reactors and one or two detectors, have been recently developed in order to increase sensitivity and accuracy and to address the issue of rapid changes of concentrations which introduce error in the radical determination (Cantrell et al., 1996b; Green et al., 2003).

This manuscript describes and reports on the DUALER instrument (DUal channel Airborne peroxy radical chemicaL amplifiER), developed at the Institute of Environmental Physics of the University of Bremen (IUP-UB), and its deployment onboard a research aircraft for the measurement within the AMMA (African Monsoon Multidisciplinary Analyses) experimental campaign which took place during the African monsoon period in August 2006. The IUP-UB DUALER utilises a common inlet, and comprises a double reactor and two identical detectors kept at a constant pressure. In the following sections, the characteristics of the instrument, calibration procedures and performance during the campaign are discussed in detail. Some modelling and analysis is used to support the interpretation of the data.

\section{Experimental}

\subsection{Description of the set up}

The PeRCA technique has been described in detail elsewhere (Hastie et al., 1991; Cantrell et al., 1993; Clemitshaw et al., 1997, 2004). Briefly, it uses the conversion of ambient peroxy radicals into nitrogen dioxide $\left(\mathrm{NO}_{2}\right)$, which is then detected by measuring the chemiluminiscence of its reaction with luminol (3-aminophthalhydrazide: $\mathrm{C}_{8} \mathrm{H}_{7} \mathrm{~N}_{3} \mathrm{O}_{2}$ ). Generally, oxy, alkoxy, hydroxy and alkylperoxy radicals $\left(\mathrm{OH}+\mathrm{RO}+\mathrm{HO}_{2}+\Sigma \mathrm{RO}_{2}\right)$ are all converted into $\mathrm{NO}_{2}$. As $\mathrm{RO}$ and $\mathrm{OH}$ abundances in the troposphere are much lower, PeRCA measures to a good approximation the total sum of peroxy radicals $\mathrm{RO}_{2}^{*}\left(\mathrm{RO}_{2}^{*}=\mathrm{HO}_{2}+\Sigma \mathrm{RO}_{2}\right)$.

The conversion of $\mathrm{RO}_{2}^{*}$ into $\mathrm{NO}_{2}$ is accomplished by adding nitrogen monoxide (NO) and $\mathrm{CO}$ to the sampled air in a specially designed reactor. This leads to a chain reaction the length of which determines the number of $\mathrm{NO}_{2}$ molecules produced per peroxy radical and consequently the chemical amplification of the signal. The chain length is defined by the competition of the chain propagating reactions:

$$
\begin{aligned}
& \mathrm{HO}_{2}+\mathrm{NO} \longrightarrow \mathrm{NO}_{2}+\mathrm{OH} \\
& \mathrm{OH}+\mathrm{CO}+\mathrm{O}_{2} \stackrel{\mathrm{M}}{\longrightarrow} \mathrm{CO}_{2}+\mathrm{HO}_{2} \\
& \mathrm{RO}_{2}+\mathrm{NO} \longrightarrow \mathrm{NO}_{2}+\mathrm{RO} \\
& \mathrm{RO}+\mathrm{O}_{2} \longrightarrow \mathrm{HO}_{2}+\text { organic products }
\end{aligned}
$$

and the chain terminating reactions, mainly being:

$$
\begin{aligned}
& \mathrm{OH}+\mathrm{NO} \stackrel{\mathrm{M}}{\longrightarrow} \mathrm{HONO} \\
& \mathrm{RO}_{2}^{*}+\text { walls } \longrightarrow \text { non radical products } \\
& \mathrm{HO}_{2}+\mathrm{NO}_{2} \stackrel{\mathrm{M}}{\longrightarrow} \mathrm{HO}_{2} \mathrm{NO}_{2} \\
& \mathrm{HO}_{2}+\mathrm{HO}_{2} \longrightarrow \mathrm{H}_{2} \mathrm{O}_{2}+\mathrm{O}_{2} \\
& \mathrm{OH}+\mathrm{HO}_{2} \longrightarrow \mathrm{H}_{2} \mathrm{O}+\mathrm{O}_{2}
\end{aligned}
$$

Under typical operating conditions, the radical-radical reactions play a negligible role in the termination of the radical amplification process.

A modulated signal is obtained by alternatively adding $\mathrm{NO}$ with $\mathrm{CO}$ and $\mathrm{NO}$ with nitrogen $\left(\mathrm{N}_{2}\right)$ to the reactor. In the absence of $\mathrm{CO}$ the peroxy radicals decay quickly and only a few pptv of $\mathrm{NO}_{2}$ are produced from the reaction of the sampled peroxy radicals with $\mathrm{NO}$. As a result, the $\mathrm{NO}_{2}$ comprising that in outside air plus other background trace gases producing $\mathrm{NO}_{2}$ in their reaction with $\mathrm{NO}$ like $\mathrm{O}_{3}$ is measured in the so called "background mode". When CO is added, the conversion of radicals takes place and the total $\mathrm{NO}_{2}$ in the so called "amplification mode" (i.e., $\mathrm{NO}_{2}$ from the conversion of peroxy radicals plus other background trace gases producing $\mathrm{NO}_{2}$ in their reaction with $\mathrm{NO}$, plus $\mathrm{NO}_{2}$ itself) is measured. The content of peroxy radicals in the air can be calculated from the difference between the signals of both modes, $\Delta \mathrm{NO}_{2}$, provided that the length of the chain reaction is determined. This is usually undertaken extensively in the laboratory (see Sect. 2.2) and regularly monitored during campaigns.

The DUALER inlet shown in Fig. 1 was developed at the IUP-UB. It comprises a double reactor sampling from a common pre-reactor nozzle and connected to two identical luminol detectors installed in a rack.

The ambient air is mixed with $\mathrm{NO}$ and $\mathrm{CO}$ as soon as it reaches the reactors $(21 \mathrm{~mm} \mathrm{ID,} 310 \mathrm{mmL}$ stainless steel cylinders, $10 \mathrm{~mm}$ inlet orifice) and this mixture is pumped through each reactor to its detector. The inner wall of the reactors is Teflon coated. In order to ensure thorough mixing, the addition gases are forced into the reactor through a series of 8 orifices ( $1.5 \mathrm{~mm}$ ID) drilled radially at the top 

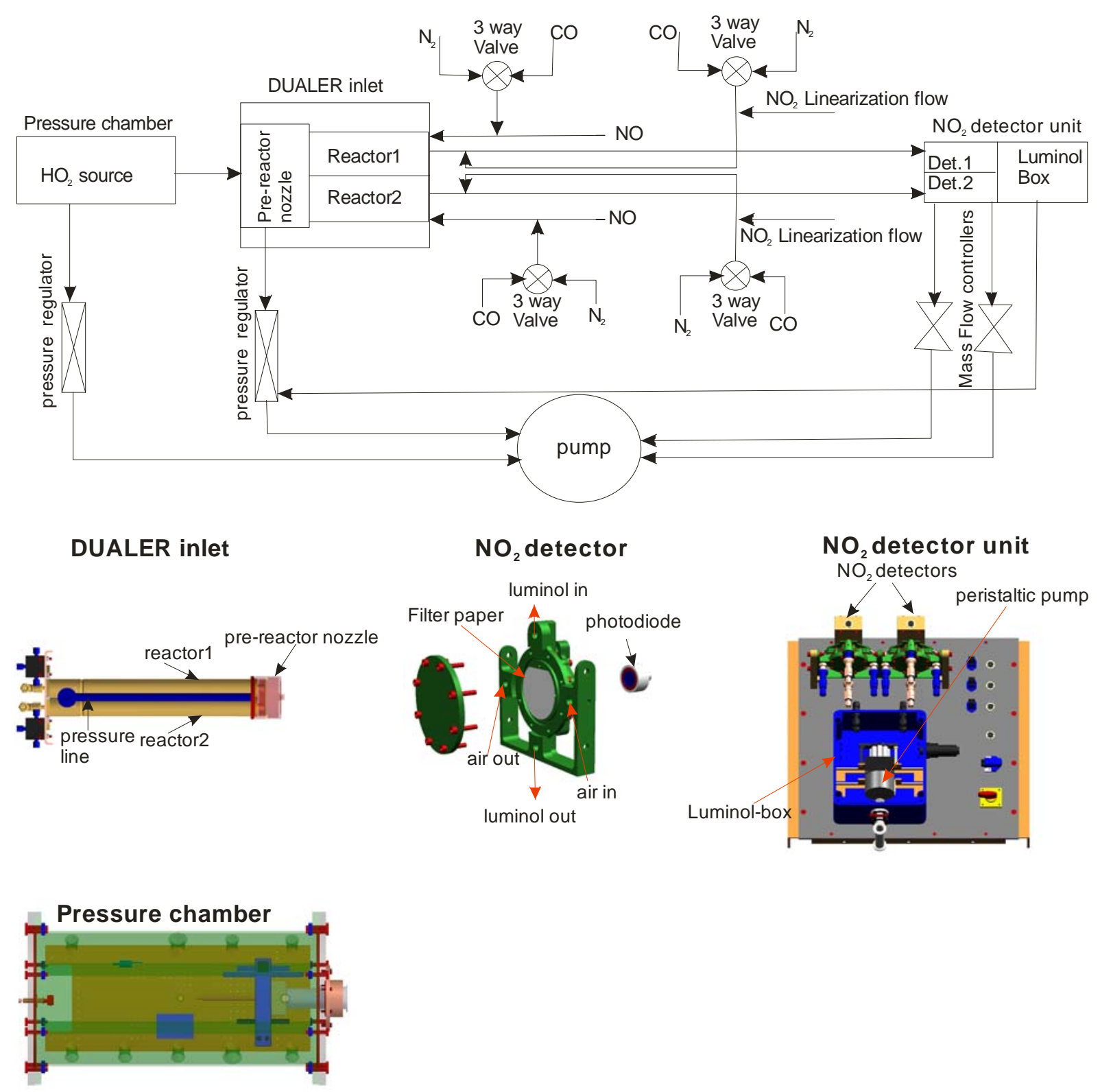

Fig. 1. Schematic presentation of the instrumental set up used for characterisation experiments and detail of some of the components of the IUP-UB DUALER.

part of each reactor. The detector unit consists of a peristaltic pump for wetting with a $5 \times 10^{-4} \mathrm{M}$ luminol solution two Whatman glass fibre filters located in front of two identical photodiodes (Fig. 1). A NO 2 offset of $20 \mathrm{ppb}$ is added to the luminol detectors in order to assure their linear response at low ambient $\mathrm{O}_{3}$ concentrations (Clemitshaw et al., 1997). Input and exhaust gas flows are purified using appropriate chemical converters: e.g. charcoal/iodine removes iron and nickel carbonyls from $\mathrm{CO}$; iron (II) sulfate $\left(\mathrm{FeSO}_{4}\right)$ removes traces of $\mathrm{NO}_{2}$ in $\mathrm{NO}$, and activated charcoal with platinum in aluminium pellets at a temperature $T>100^{\circ} \mathrm{C}$ converts the $\mathrm{CO}$ in the exhaust to carbon dioxide $\left(\mathrm{CO}_{2}\right)$.
Data are acquired with a DT 322 Multifunction Data Acquisition Board having an analog digital conversion rate of $200 \mathrm{kSA} / \mathrm{s}$ per channel, $30 \mathrm{~Hz}$ averages being saved. Homemade software is used to switch three way valves in the inlet system every $60 \mathrm{~s}$ alternating the modes of the reactors. In such a way it is possible to have continuous information about total and background $\mathrm{NO}_{2}$ which are separately and simultaneously measured by both detectors.

An important aspect of the IUP-UB DUALER is the pressure regulation (see Sect. 3). This is achieved at the so called pre-reactor nozzle, located in front of the reactors. As shown in Fig. 1, the air coming through a $1 \mathrm{~mm}$ nozzle reaches first 
Table 1. Operating flow conditions at the DUALER reactor during AMMA.

\begin{tabular}{lcc}
\hline Gas & $\begin{array}{r}\text { Flow rate } \\
(\mathrm{ml} / \mathrm{min})\end{array}$ & $\begin{array}{c}\text { Reactor } \\
\text { concentration }\end{array}$ \\
\hline Sampling air & 500 & - \\
600 ppmv NO in $\mathrm{N}_{2}$ & 2.5 & $3 \mathrm{ppmv}$ \\
$\mathrm{CO}(99.97 \%$ purity $)$ & 37 & $7.4 \%$ \\
$\mathrm{~N}_{2}(99.999 \%$ purity $\left.)\right)$ & 37 & $\approx 75 \%$ \\
$\mathrm{NO}_{2} 1$ ppmv in SA & 10 & $20 \mathrm{ppbv}$ \\
\hline
\end{tabular}

a volume of $54.5 \mathrm{~cm}^{3}$, which is kept at a constant pressure by using a pressure controller (Bronkhorst, HI-TEC, F-004BIIV-55-V). The pressure line is connected to the sampling line behind the detectors and both are connected to the vacuum pump. In this manner the detector system is held at a settable, constant pressure. In order to prevent pressure variations when switching the measurement modes, a flow of $\mathrm{N}_{2}$ or $\mathrm{CO}$ appropriately is added at the second addition point, at the bottom of the reactor.

For the AMMA flights (Andrés-Hernández et al., 2009; Reeves et al., 2010) the DUALER was kept at 200 mbar. To comply with safety regulations for the total volume of $\mathrm{CO}$ allowed onboard the DLR-Falcon, the flows were adjusted to reach 3 ppmv NO and $7.4 \%$ CO added to the ambient flow; the total sampling flow rate at each reactor being $0.5 \mathrm{~s} \mathrm{~L} \mathrm{~min}^{-1}$. Table 1 summarises the operating flow conditions and concentrations during AMMA. The gas residence time in each reactor and in the line connecting the reactor to the detector is therefore ca. $1.3 \mathrm{~s}$, and $0.5 \mathrm{~s}$, respectively. The gas residence time in the pre-reactor nozzle varies depending on the $\Delta P=P_{\text {ambient }}-P_{\text {reactor }}$ (see Sect. 3).

\subsection{Calibration procedures}

The sensitivity of the DUALER instrument relies both on the efficiency of the conversion of radicals into $\mathrm{NO}_{2}$ at the reactor, i.e., the chain length (CL), and on the performance of the $\mathrm{NO}_{2}$ detector. The calibration procedure must therefore comprise regular $\mathrm{CL}$ and $\mathrm{NO}_{2}$ calibrations. The known dependency of the $\mathrm{CL}$ on the relative humidity $(\mathrm{RH})$ of the air sampled (Mihele and Hastie, 1998; Mihele et al., 1999; Reichert et al., 2003) has a negligible effect under the AMMA measurement conditions. The DUALER inlet was not heated during the AMMA flights but its inner part was connected to the cabin of the aircraft. As a consequence, the temperature of the reactors always remained higher than that of the outside air. Therefore, the RH, $\left(P_{\text {partial }}^{\mathrm{H}_{2} \mathrm{O}} / P_{\text {saturation }}^{\mathrm{H}_{2} \mathrm{O}}\right)$, decreases in the reactors with respect to the ambient as $T_{\text {ambient }}<T_{\text {reactor }}$ causes the increase in $P_{\text {saturation }}^{\mathrm{H}_{2} \mathrm{O}}$, and $P_{\text {ambient }}>P_{\text {reactor }}$ causes the decrease in the $P_{\text {partial }}^{\mathrm{H}_{\mathrm{O}} \mathrm{O}}$ in the reactors (Kartal, 2009).
Table 2. Geometrical features of main components of the calibration set up.

\begin{tabular}{lccc}
\hline & $\begin{array}{c}\text { DUALER pre- } \\
\text { reactor nozzle }\end{array}$ & $\begin{array}{c}\text { DUALER } \\
\text { reactor }\end{array}$ & $\begin{array}{c}\text { Pressure } \\
\text { chamber }\end{array}$ \\
\hline Orifice diameter & $1 \mathrm{~m}$ & $10 \mathrm{~mm}$ & $49.5 \mathrm{~cm}$ \\
Inner diameter & $63 \mathrm{~mm}$ & $21 \mathrm{~mm}$ & $49.5 \mathrm{~cm}$ \\
Length & $13 \mathrm{~mm}$ & $31 \mathrm{~mm}$ & $105 \mathrm{~cm}$ \\
Volume & $55 \mathrm{~cm}^{3}$ & $10.7 \mathrm{~cm}^{3}$ & $0.2 \mathrm{~m}^{3}$ \\
\hline
\end{tabular}

The $\mathrm{NO}_{2}$ response of the instrument detectors is calibrated regularly by adding different $\mathrm{NO}_{2}$-air mixtures from calibrated air cylinders.

The CL calibration of the reactor is based on the production of radicals from the UV photolysis of water $\left(\mathrm{H}_{2} \mathrm{O}\right)$ at $184.9 \mathrm{~nm}$ (Schultz et al., 1995). The IUP-UB calibration source has been described in detail elsewhere (Reichert et al., 2003). Briefly, a known water-air mixture is photolysed with a low pressure mercury $(\mathrm{Hg})$ lamp which intensity is attenuated by using a nitrous oxide $\left(\mathrm{N}_{2} \mathrm{O}\right)$ filter, i.e., varying the $\mathrm{N}_{2} \mathrm{O} / \mathrm{N}_{2}$ ratio in the absorption zone. $\mathrm{CO}$ is added to the gas mixture to convert the $\mathrm{OH}$ produced into $\mathrm{HO}_{2}$ radicals. As the amount of radicals is proportional to the intensity of light, and the absorption coefficient of $\mathrm{N}_{2} \mathrm{O}$ (Cantrell et al., 1997) does not change significantly around $185 \mathrm{~nm}\left(\sigma_{\mathrm{N} 2 \mathrm{O}}=14.05 \times 10^{-20} \mathrm{~cm}^{2}\right.$ molecule $^{-1}$ at $25^{\circ} \mathrm{C}$ with a $0.02 \times 10^{-20} \mathrm{~cm}^{2}$ molecule ${ }^{-1} \mathrm{~K}^{-1}$, temperature dependency), different $\mathrm{HO}_{2}$ radical amounts can be produced for a constant $\mathrm{H}_{2} \mathrm{O}$ concentration:

$\left[\mathrm{HO}_{2}\right]=\frac{\sigma_{\mathrm{H}_{2} \mathrm{O}}^{184.9 \mathrm{~nm}}\left[\mathrm{H}_{2} \mathrm{O}\right]}{\sigma_{\mathrm{O}_{2}}^{184.9 \mathrm{~nm}}\left[\mathrm{O}_{2}\right]}\left[\mathrm{O}_{3}\right]$

$\sigma_{i}$ being the corresponding absorption cross sections at $184.9 \mathrm{~nm}$.

In order to characterise the performance of the instrument for airborne application, a series of measurements were performed under controlled pressure, $P$, conditions by deploying the calibration source in a pressure chamber of $0.2 \mathrm{~m}^{3}$, which can be evacuated down to $100 \mathrm{mbar}$. The experimental set up is depicted schematically in Fig. 1 and main geometrical features are summarised in Table 2.

\section{Characterisation of the DUALER for airborne measurements}

An important aspect of the airborne measurement of radicals is the stability of the instrument performance during the flight. Therefore a main issue of the characterisation of the IUP-UB DUALER was the variation of the $\mathrm{NO}_{2}$ signal and the chain length with the pressure. 


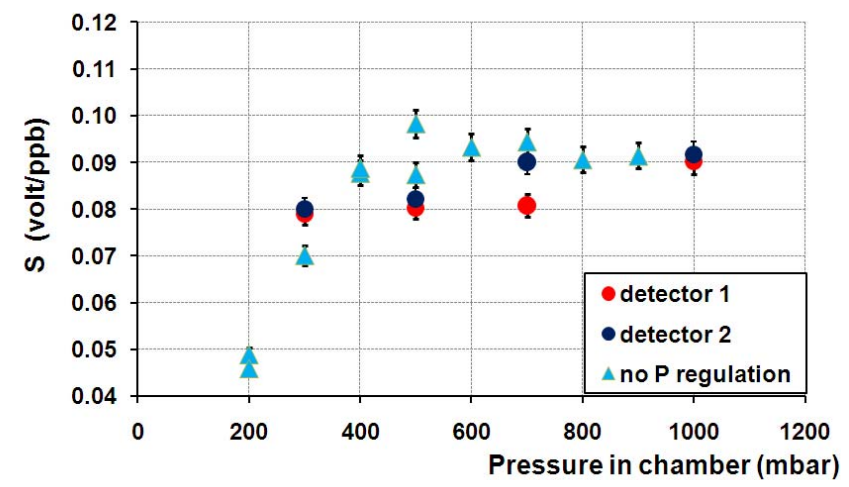

Fig. 2. Variation of the detector sensitivity $(S)$ with the pressure. $S$ is defined as $1 / a, \mathrm{NO}_{2}$ being $\mathrm{NO}_{2}=a X+b$; and $X$ the detector signal in volts. The filter paper was changed at $500 \mathrm{mbar}$ (see text). The values in dark blue and red correspond to $\mathrm{NO}_{2}$ detectors kept at 200 mbar constant pressure.

\subsection{Variation of the $\mathrm{NO}_{2}$ sensitivity with the pressure}

Figure 2 shows the $\mathrm{NO}_{2}$ detector sensitivity determined during two series of calibrations made at pressures between ambient and 200 mbar. The detector sensitivity is defined as $S=1 / a, \mathrm{NO}_{2}$ being $\mathrm{NO}_{2}=a X+b$ and $X$ the detector signal in $V$. The detector signal degrades along each experimental series after a few days as a consequence of filter ageing. This deterioration is therefore not expected to affect the measurements performed with brand new filters over the course of a flight. Changing the filter in the detector is always associated with improved sensitivity. This was observed at $500 \mathrm{mbar}$ in the data set above.

The results show that between ambient and 500 mbar the detector sensitivity remains constant within the error $(1 \sigma \cong$ $\pm 6 \%$ ), while from 500 mbar the sensitivity decreases significantly when reducing the pressure, down to $45 \%$ at 200 mbar. This can be attributed to the increase in the volume flow through the detector which above a certain threshold may lead to a drying out of the luminol on the filter. As the instrument measures $\mathrm{NO}_{2}$ concentration, the decrease of the number of molecules involved in the luminescent reaction with decreasing the pressure might explain some of the observed behaviour below 500 mbar.

Changes in the pressure of the air sampled lead to a transition period of about $15 \mathrm{~min}$, characterised by signal noise and instabilities in the detector sensitivity. In addition to the pressure dependency of the luminol chemistry mentioned above, instabilities in the luminol flow affect critically the sensitivity and overall performance of the luminol detectors.

Once the detector has stabilised at a particular pressure (i.e., $\pm 0.15 \%$ variability), both signal and sensitivity remain fairly steady until the next pressure change as shown in Fig. 2 with 2 calibrations performed at $400 \mathrm{mbar}$. The variation of the detector sensitivity with ambient pressure when the de- tector pressure is kept at 200 mbar is additionally shown in Fig. 2 for comparison.

These results show the necessity to maintain the PeRCA detector at a constant pressure during airborne measurements in order to maximise the number and representativeness of observations. This has impact on the aircraft flight patterns selected for the determination of atmospheric vertical profiles and the identification of short term pollution events.

\subsection{Variation of the $\mathrm{CL}$ with the pressure}

The extent of the chain reaction depends not only on the concentration of the reactants and the residence time in the reactor but also on the material and shape of the reactor, as it results from the competition between amplification, chemical loss reactions and wall loses (Reichert et al., 2003). As mentioned above, given the value of the $\mathrm{CL}$, the $\mathrm{RO}_{2}^{*}$ concentration in the air sampled can be calculated as:

$\left[\mathrm{RO}_{2}^{*}\right]=\left[\mathrm{HO}_{2}\right]+\sum\left[\mathrm{RO}_{2}\right]=\frac{\Delta\left[\mathrm{NO}_{2}\right]}{\mathrm{CL}}$

The pressure variation of the CL for the reactors constituting the IUP-DUALER was determined experimentally using a $\mathrm{HO}_{2}$ source in which the produced $\mathrm{HO}_{2}$ is calculated according to Eq. (1). For this, the oxygen $\left(\mathrm{O}_{2}\right)$ effective cross section must be determined as it depends on the lamp conditions and the $\mathrm{O}_{2}$ column (Hofzumahaus et al., 1997; Creasy et al., 2000), and the latter varies at different pressures. The apparent $\sigma_{\mathrm{O} 2}$ is determined from the total absorption measured at different $\mathrm{O}_{2}$ in the cell by varying the flow of synthetic air (containing 20\% $\mathrm{O}_{2}$ ) and $\mathrm{N}_{2}$ through the calibration source. As only the central portion of the flow is sampled by the instrument, for the determination of the peroxy radical concentration the calculation of the effective $\sigma_{\mathrm{O} 2}$ locally at this position in the photolysis region is required. This is described in more detail elsewhere (Creasy et al., 2000; Kartal, 2009). Both apparent and effective $\sigma_{\mathrm{O} 2}$ for the calibration set up used in the present work are shown at different pressures in Fig. 3.

The obtained experimental pressure dependency of the CL is shown in Fig. 4, where CL calibrations were made by connecting a single reactor to the radical source installed inside the pressure chamber, and by varying the pressure between 200 and 1000 mbar. A decrease in the pressure of the sampling air is associated with an increase in the volume flow through the reactor since the mass flow through the instrument is kept constant during the measurement. Provided that the retention time in the reactor is sufficient for the chain reaction to be completed, the CL is expected to decrease when decreasing the ambient pressure, as the wall losses are gaining in importance as a consequence of the lower probability of molecular collisions at lower pressures. This behaviour is in agreement with the results in Fig. 4 and with previous experiments with other reactors (Kartal, 2004).

A box model accounting for the main reactions involved (see Appendix A) was used to simulate the CL pressure 


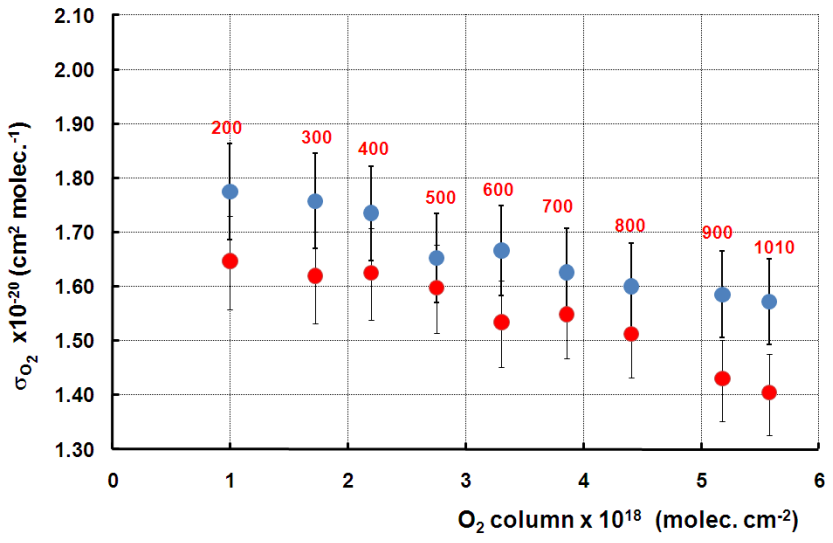

Fig. 3. Apparent (blue dots) and effective (red dots) $\mathrm{O}_{2}$ absorption cross section obtained experimentally at different pressures (in red) for the calibration set up used in this work.

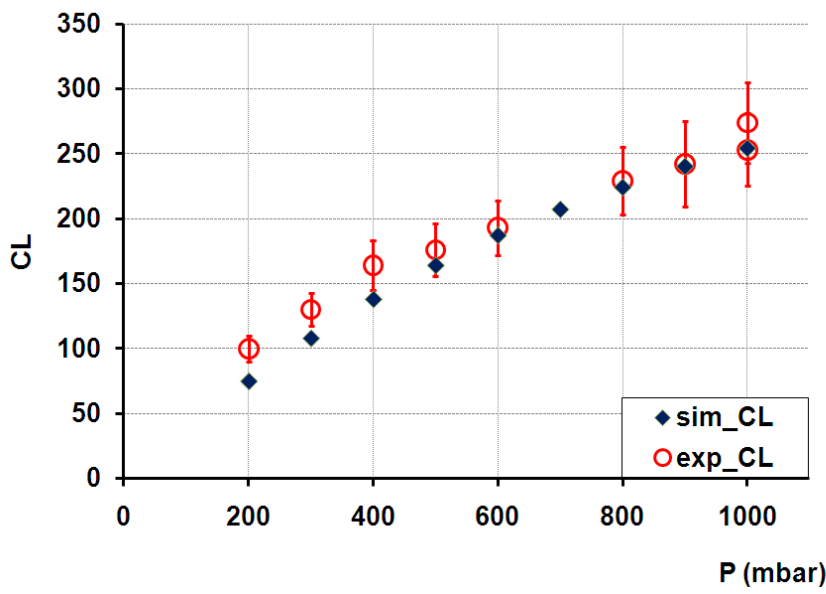

Fig. 4. Variation of the CL with the pressure as measured for a single reactor. Simulated (sim-CL) and experimental CL (exp_CL) are plotted for comparison.

dependency. The wall losses were constrained to the measurements at 1000 mbar leading to a $k_{\text {wall }}^{\mathrm{HO}_{2}}=1.5 \mathrm{~s}^{-1}$, and kept constant for the whole pressure range. According to this, $1.2 \mathrm{~s}$ and $1.8 \mathrm{~s}$ are the minimum retention times required to complete the chain reaction at 1000 and 200 mbar respectively. Generally the agreement is very reasonable but for $P<400$ mbar the simulations underestimate slightly the CL obtained experimentally. This indicates that the variations with the pressure are either underestimated for the propagating reactions or overestimated for the terminating reactions (see Sect. 2.2). Provided that the increase of $k_{\mathrm{CO}+\mathrm{OH}}$ with the pressure has been thoroughly studied (Sander et al, 2006), the discrepancies must be caused by the terminating reactions. The pressure variation of the experimental CL can be simulated by replacing $k_{\text {wall }}$ with a total $k_{\text {loss }}=1.5-\left(P_{1} /\left(10 \cdot P_{2}\right)\right)$, where $P_{1}=1013.15 \mathrm{mbar}, P_{2}$ is the measurement pressure and $k_{\text {loss }}$ is expressed in $\mathrm{s}^{-1}$.

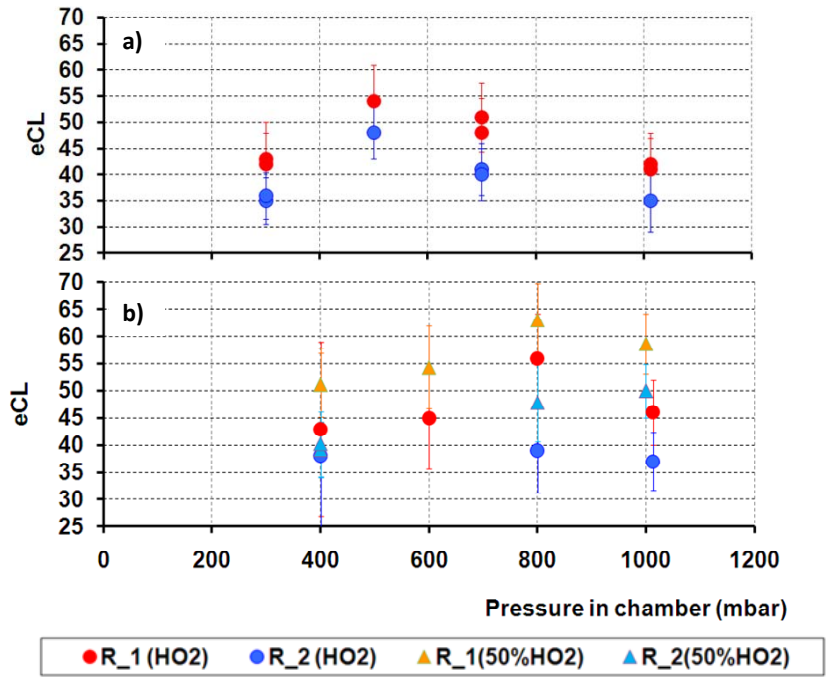

Fig. 5. Variation of the eCL with the ambient pressure. The IUPDUALER is kept at a constant pressure: (a) $200 \mathrm{mbar}$, (b) $300 \mathrm{mbar}$. $R-i\left(50 \% \mathrm{HO}_{2}\right)$ corresponds with a $50 \% \mathrm{HO}_{2} / 50 \% \mathrm{CH}_{3} \mathrm{O}_{2}$ radical mixture for reactor $i$.

As mentioned in Sect. 3.1 the signal instability of the luminol detector requires keeping the instrument pressure constant during airborne measurements. This is achieved by regulating the pressure at the pre-reactor nozzle previous to the reactors, as described in the experimental section. For this DUALER, the CL measured in the laboratory is an effective $\mathrm{CL}$ (eCL) which is lower than the CL determined for the single reactor at the same pressure, since only the radicals not being lost in the pre-reactor nozzle are participating in the chain reaction at the reactor. As the peroxy radicals are reacting rapidly with the walls, the losses at this nozzle before the addition of $\mathrm{CO}$ and $\mathrm{NO}$ are expected to be important.

Figure 5 shows the eCL measured at different ambient pressures but keeping constant the pressure of the DUALER. It is important to note that the eCL in both reactors is not identical. This is likely a consequence of slight mechanical differences in the detectors affecting the interface between the luminol solution and the air sample and therefore the chemiluminiscent reaction.

As expected, the eCL is lower than the CL determined for the single reactor without pre-reactor nozzle. When keeping the DUALER at a constant pressure the eCL remains fairly constant within reproducibility and there is no significant difference in the results obtained at 200 and 300 mbar. The light curvature observed in the results in Fig. 5 is though very reproducible. This is interpreted to be related to $\Delta P=$ $P_{\text {sample }}-P_{\text {DUALER }}$. Due to the pressure regulation the air sample flows with higher velocity through the pre-reactor nozzle at higher $\Delta P$, what minimises the radical residence time in the pre-reactor nozzle and therefore the likeness of wall losses. However, high velocities are associated with turbulences which might enhance wall losses in the pre-reactor 
(a)

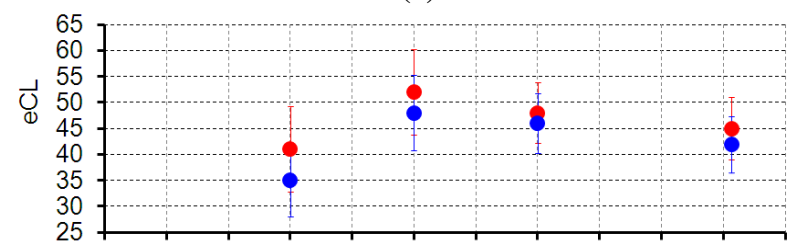

(b)

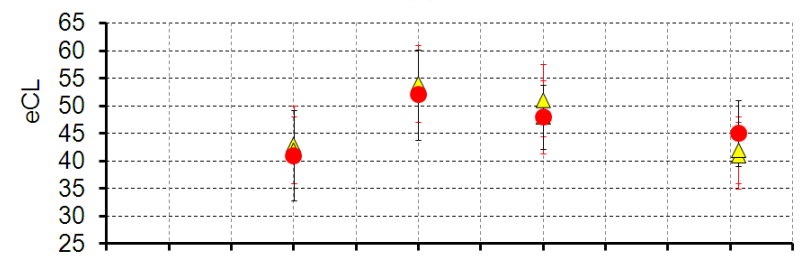

(c)

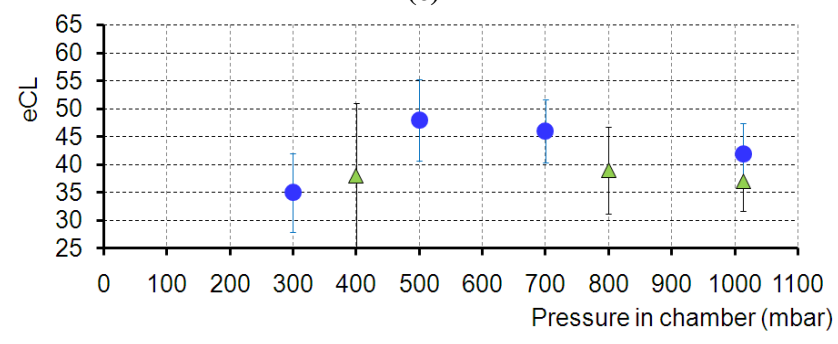

Fig. 6. Variation of the eCL with the ambient pressure for the DUALER (a) without pressure regulation, (b) regulated at $200 \mathrm{mbar}$ and (c) regulated at $300 \mathrm{mbar}$. The eCL obtained without pressure regulation is also plotted in (b) and (c) for comparison (red dots: reactor 1; blue dots: reactor 2 ).

nozzle. Low $\Delta P$ is linked to less turbulence but to longer radical retention times in the pre-reactor nozzle. At different $\Delta P$ the eCL is therefore the result of these competing mechanisms in the wall losses which may reach a compensation point at about 600 mbar.

This is confirmed by the results obtained when the DUALER pressure is not regulated, up to $500 \mathrm{mbar}$ (Fig. 6). As the flow across the $1 \mathrm{~mm}$ orifice of the pre-reactor nozzle is laminar, the pressure drop $\left(P_{\mathrm{d}}\right)$ for each chamber pressure can be calculated. $P_{\mathrm{d}}$ decreases from $12 \mathrm{mbar}$ at $200 \mathrm{mbar}$ to $2.5 \mathrm{mbar}$ at $1000 \mathrm{mbar}$. Therefore, $\Delta P=P_{\text {sample }}-$ $P_{\text {DUALER }} \cong 0$. The corresponding eCL NPR $_{\text {(eCL }}$ NPR: eCL no pressure regulation) decrease linearly with increasing chamber pressures, i.e., with higher retention time of the sample in the pre-reactor nozzle. Interestingly, while the eCL $L_{N P R} a b-$ solute values are of the same order of magnitude than in the pressure regulated system, the discrepancies increase with increasing pressure (Fig. 6), so that at the maximum $\Delta P$, $\mathrm{eCL}_{\mathrm{NPR}}>\mathrm{eCL}$ This is consistent with the presence of additional turbulences at the pre-reactor nozzle associated with the pressure regulation, enhancing the radical wall losses. As expected $\mathrm{eCL}_{\mathrm{NPR}} \cong \mathrm{eCL}$ when the DUALER is kept at 200 mbar.

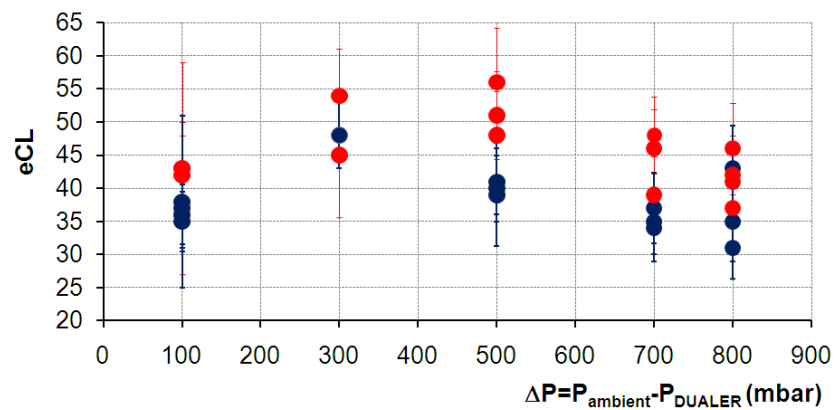

Fig. 7. Experimental eCL values obtained for different $\Delta P=P_{\text {ambient }}-P_{\text {DUALER }}$. The DUALER is kept at 200 mbar. In red eCL for reactor 1 and in blue for reactor 2 .

The implementation of the pressure regulation requires therefore a characterisation of the eCL in the reactors respect to $\Delta P$ during the measurement (see Fig. 7). For airborne measurements the maximum eCL is reached by $\Delta P$ around 500 mbar.

\subsection{Estimation of radical wall losses in the pre-reactor nozzle}

Using a pure $\mathrm{HO}_{2}$ calibration source, the $\mathrm{HO}_{2}$ wall loss rate $\left(k_{\text {wall }}^{\mathrm{HO}_{2}}\right)$ can be estimated from the comparison between experimental CLs obtained at different pressures for the single reactor (i.e., CL) and for the DUALER reactor without regulating the pressure (i.e., $\mathrm{eCL}_{\mathrm{NPR}}$; NPR: non pressure regulation).

The total radical loss in the pre-reactor nozzle can be calculated from:

$\left[\mathrm{HO}_{2}\right]_{t^{*}}=\left[\mathrm{HO}_{2}\right]_{0} e^{-k_{\mathrm{loss}} t^{*}}$

$\left[\mathrm{HO}_{2}\right]_{0}$ and $\left[\mathrm{HO}_{2}\right]_{t} *$ are respectively the mixing ratios entering the pre-reactor nozzle and entering the reactors, $k_{\text {loss }}$ is the total radical loss rate, and $\left[\mathrm{HO}_{2}\right]_{t^{*}}=\left[\mathrm{HO}_{2}\right]_{0}-\left[\mathrm{HO}_{2}\right]_{\text {loss }}$, $\left[\mathrm{HO}_{2}\right]_{\text {loss }}$ being the radical loss by a retention time $t^{*}$ in the nozzle.

The losses in the pre-reactor nozzle are the result of wall losses and radical-radical reactions. According to model calculations (see Appendix A), chemical losses contribute $0.19 \%$ and $0.23 \%$ to the total losses at 200 and 1000 mbar, respectively. The total radical loss is therefore dominated by the wall losses, and $k_{\text {loss }}$ is an upper limit of the $k_{\text {wall }}^{\mathrm{HO}_{2}}$.

If the losses occurring in the pre-reactor nozzle are known exactly and taken into account in the calculation of the CL, the actual CL in each reactor of the DUALER and in the single reactor without pre-reactor nozzle must be the same. Thus:

$$
\frac{\Delta \mathrm{NO}_{2 . \text { DUALER }}}{\left[\mathrm{HO}_{2}\right]_{0}-\left[\mathrm{HO}_{2}\right]_{\text {loss }}}=\frac{\Delta \mathrm{NO}_{2 . \text { SINGLE }}}{\left[\mathrm{HO}_{2}\right]_{0}}=\mathrm{CL}
$$




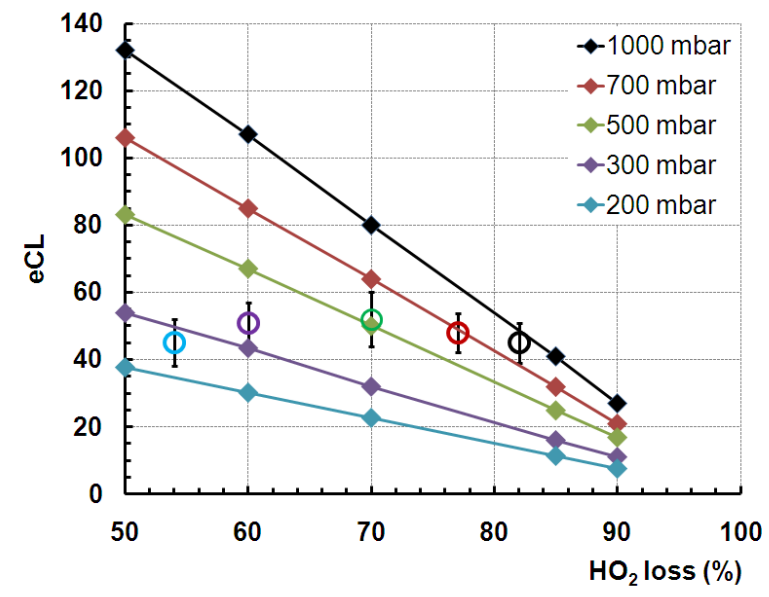

Fig. 8. $\mathrm{HO}_{2}$ losses at the pre-reactor nozzle for eCL at different pressures calculated from $\mathrm{eCL}_{\mathrm{NPR}}$, measurements without DUALER pressure regulation, (empty circles) and a chemical box model with a $\mathrm{HO}_{2}$ radical trap.

As eCL is calculated as eCL $=\Delta \mathrm{NO}_{2}$ DUALER $/\left[\mathrm{HO}_{2}\right]_{0}$, then:

$\frac{\left[\mathrm{HO}_{2}\right]_{\text {loss }}}{\left[\mathrm{HO}_{2}\right]_{0}}=1-\frac{\mathrm{eCL}}{\mathrm{CL}} ;$

Figure 8 shows the $\mathrm{HO}_{2}$ losses at the pre-reactor nozzle calculated by Eq. (5) and on the basis of the experimental values of $\mathrm{CL}$ and eCL. These values agree very reasonably with simulations of the $\mathrm{eCL}_{\mathrm{NPR}}$ at different pressures performed with the chemical box model described in Appendix A combined with a numerical trap removing radicals before amplification.

The Eq. (5) is also applicable to the $\mathrm{eCL}_{\mathrm{NPR}}$. The $k_{\text {loss }}$ can be calculated from the experimental values of $e^{2} L_{N P R}$ and CL:

$k_{\mathrm{loss}}=\frac{1}{t^{*}} \ln \frac{\left[\mathrm{HO}_{2}\right]_{0}}{\left[\mathrm{HO}_{2}\right]_{t^{*}}}$

The variation of $k_{\text {loss }}$ with the pressure is depicted in Fig. 9. As stated above, this $k_{\text {loss }}$ represents an upper limit of $k_{\text {wall }}$. According to Hayman (1997):

$k_{\text {wall }}=1.85\left(\frac{v^{1 / 3} D^{2 / 3}}{d^{1 / 3} L^{1 / 3}}\right)\left(\frac{S}{V}\right) ;$

where $v$ is the velocity of the gas $\left(\mathrm{cm} \mathrm{s}^{-1}\right), D$ the diffusion coefficient $\left(\mathrm{cm}^{2} \mathrm{~s}^{-1}\right), L$ the length $(\mathrm{cm}), d$ the diameter of the flow tube (cm), $S$ the surface area $\left(\mathrm{cm}^{2}\right)$ and $V$ the volume $\left(\mathrm{cm}^{3}\right)$.

In the case of the pre-reactor nozzle, $S, V, d$, and $L$ remain constant at all the pressures and Eq. (7) can be rewriten as:

$k_{\mathrm{wall}}=Z\left(v^{1 / 3} D^{2 / 3}\right)$;

where $Z$ is a constant. According to Eq. (8), the $k_{\text {loss }}$ is expected to decrease with increasing pressures since the diffussion coefficient $D(D=\lambda c / 3, \lambda$ being the mean free path,

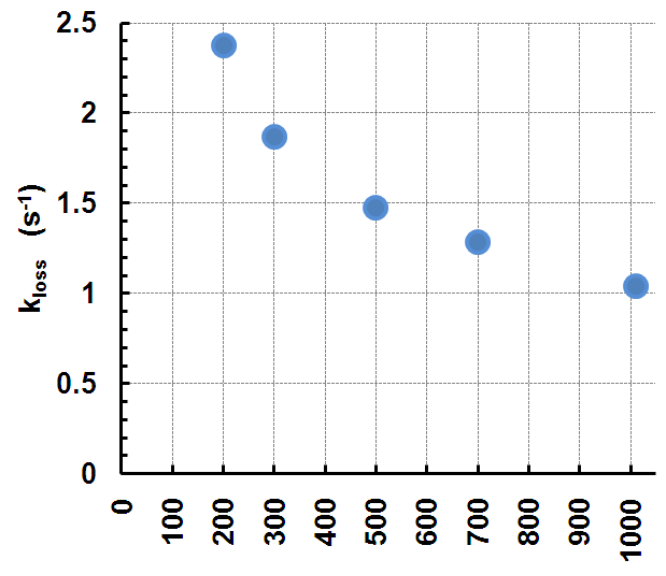

Pressure (mbar)

Fig. 9. Variation of the $\mathrm{HO}_{2}$ radical $k_{\text {loss }}$ according to experimental eCL $L_{\text {NPR }}$ and CL values. $k_{\text {loss }}$ represents an upper limit of $k_{\mathrm{wall}}$ since the chemical losses are $\sim 0.2 \%$ (see text).

and $c$ the mean molecular speed) decreases with increasing pressure at constant temperature, as result of the decrease in the mean free path. In addition, the velocity of the gas sample through the pre-reactor nozzle decreases when increasing the pressure as the mass flows are kept constant at all the pressures. This is in agreement with the values presented in Fig. 9.

According to the results shown in Fig. 8, the $\mathrm{HO}_{2}$ losses at the pre-reactor nozzle are estimated to be around 55\% at 200 mbar. This situation is closest to the conditions during the AMMA airborne measurements when the DUALER system was kept constantly at 200 mbar.

The wall losses of alkyl peroxy radicals are expected to be lower. A series of experiments were performed by using a methylperoxyl $\left(\mathrm{CH}_{3} \mathrm{O}_{2}\right) / \mathrm{HO}_{2}$ radical source. This is achieved by adding methane $\left(\mathrm{CH}_{4}\right)$ instead of $\mathrm{CO}$ in the calibration gas:

$\mathrm{H}_{2} \mathrm{O}+h v(\lambda=184.9 \mathrm{~nm}) \rightarrow \mathrm{H}+\mathrm{OH}$

$\mathrm{H}+\mathrm{O}_{2} \stackrel{\mathrm{M}}{\longrightarrow} \mathrm{HO}_{2}$

$\mathrm{OH}+\mathrm{CH}_{4}+\mathrm{O}_{2} \stackrel{\mathrm{M}}{\longrightarrow} \mathrm{CH}_{3} \mathrm{O}_{2}+\mathrm{H}_{2} \mathrm{O}$

As $\mathrm{CH}_{4}$ is added in excess to favour the chemical reaction over the $\mathrm{OH}$ wall losses, the source generates a $50 \% \mathrm{CH}_{3} \mathrm{O}_{2}$ and $50 \% \mathrm{HO}_{2}$ radical mixture.

Once in the reactor, the $\mathrm{HO}_{2}$ radicals lead the amplification cycle. The yield of $\mathrm{HO}_{2}$ from $\mathrm{CH}_{3} \mathrm{O}_{2}$ for the experimental conditions is 0.85 (Clemitshaw et al., 1997) and results from the reactions:

$\mathrm{CH}_{3} \mathrm{O}_{2}+\mathrm{NO} \rightarrow \mathrm{CH}_{3} \mathrm{O}+\mathrm{NO}_{2}$

$\mathrm{CH}_{3} \mathrm{O}+\mathrm{O}_{2} \rightarrow \mathrm{CH}_{2} \mathrm{O}+\mathrm{HO}_{2}$ 


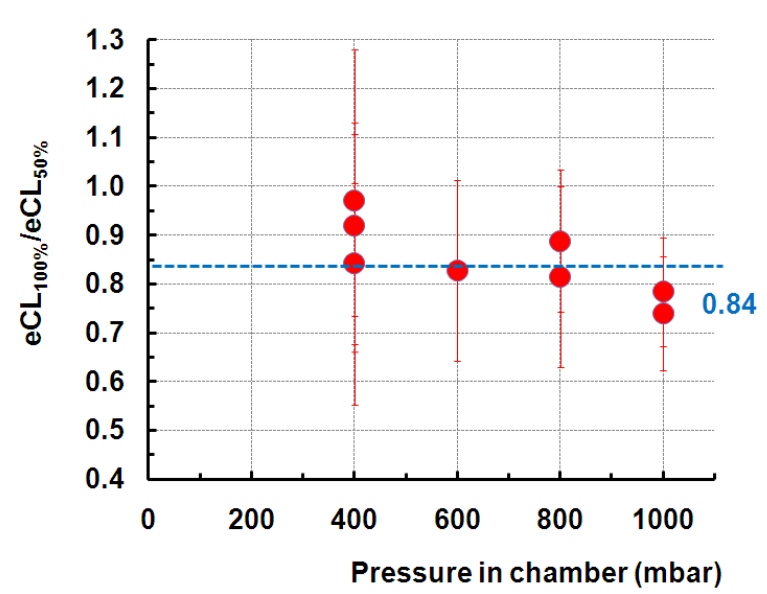

Fig. 10. Variation with the pressure of the ratio between eCLs obtained for $100 \% \mathrm{HO}_{2}$ (indicated as $\mathrm{eCL}_{100 \%}$ ) and for a mixture of $50 \% \mathrm{HO}_{2}$ plus $50 \% \mathrm{CH}_{3} \mathrm{O}_{2}$ (indicated as $\mathrm{eCL}_{50 \%}$ ). The mean ratio is 0.84 .

$\mathrm{CH}_{3} \mathrm{O}+\mathrm{NO} \stackrel{\mathrm{M}}{\longrightarrow} \mathrm{CH}_{3} \mathrm{ONO}$

The eCL is therefore experimentally determined from the $\Delta \mathrm{NO}_{2}$ measured versus $\left[\mathrm{HO}_{2}\right]$ calculated by Eq. (1) for a 0.85 yield from $\mathrm{CH}_{3} \mathrm{O}_{2}$.

As expected, the eCL for the mixture of $\mathrm{HO}_{2}$ and $\mathrm{CH}_{3} \mathrm{O}_{2}$ behaves similarly over the pressure range but the absolute values are higher than for the pure $\mathrm{HO}_{2}$ as the $\mathrm{CH}_{3} \mathrm{O}_{2}$ are less effectively lost in the pre-reactor nozzle. Figure 5 shows the eCL pressure variation for the DUALER kept at 300 mbar. The ratio $\mathrm{eCL}^{100 \% \mathrm{HO}_{2}} / \mathrm{eCL}^{50 \% \mathrm{HO}_{2}+50 \% \mathrm{CH}_{3} \mathrm{O}_{2}}$ is plotted in Fig. 10.

Based on these results, the eCL was simulated for different mixtures of $\mathrm{HO}_{2}$ and $\mathrm{CH}_{3} \mathrm{O}_{2}$. As shown in Fig. 11, if the eCL for pure $\mathrm{HO}_{2}$ is used for the analysis of all ambient measurements, i.e., assuming equal wall losses for all peroxy radicals, the $\mathrm{RO}_{2}^{*}$ mixing ratios are $14 \%$ overestimated in the case of the most common $1: 1 \mathrm{HO}_{2} / \mathrm{CH}_{3} \mathrm{O}_{2}$ ambient mixture.

\section{Processing and analysis of AMMA data}

The analysis of airborne data requires an especially careful evaluation which takes into account the experimental drawbacks during the preparation and measurement periods.

The IUP-UB DUALER was deployed during the AMMA campaign on the DLR-Falcon for the measurement of peroxy radicals during the African monsoon period in 2006 (Reeves et al., 2010; Andrés-Hernández et al., 2009). During the AMMA flight preparation periods in Ouagadougou, unavoidable interruptions in the gas flows and power supply previous to the flights led to detector instabilities which constrained the usefulness and representativeness of the calibrations. On top of this, changes in the $\mathrm{NO}_{2}$ concentration provided by the gas cylinder built in the DUALER ( 1 ppm $\mathrm{NO}_{2}$ in synthetic air) were observed throughout the day. These are attributed to

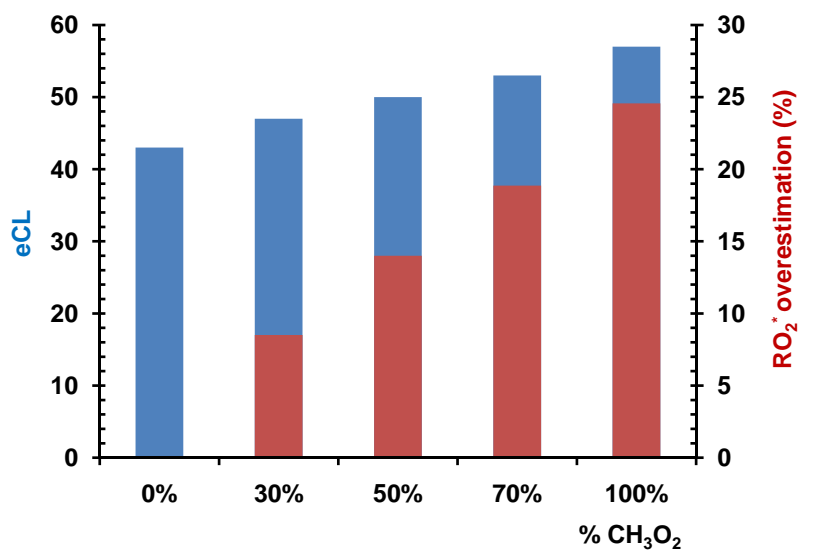

Fig. 11. Simulated eCL values for different $\mathrm{HO}_{2}$ and $\mathrm{CH}_{3} \mathrm{O}_{2}$ mixtures $\left(0 \%\right.$ implies a pure $\mathrm{HO}_{2}$ sample). Red bars represent the corresponding overestimation in the $\mathrm{RO}_{2}^{*}$ mixing ratios determined with the eCL for $\mathrm{HO}_{2}$.

the high $T$ and humidity conditions prior to the flight which possibly led to variable $\mathrm{NO}_{2}$ wall losses related to the formation of nitric acid $\left(\mathrm{HNO}_{3}\right)$ in the pressure regulator and the gas tubing in spite of lengthy flushing of the gas lines. As a consequence, in-flight calibrations with this $\mathrm{NO}_{2}$ cylinder were not possible.

Short-term instabilities in the luminol flow can also be of importance during the flight and must be carefully taken into account in the data processing. The flow instabilities lead to short-term and not simultaneous variations in the sensitivities of the detectors which might introduce uncertainties in the determination of $\Delta \mathrm{NO}_{2}$, i.e., $\mathrm{NO}_{2}$ amplification $-\mathrm{NO}_{2}$ background, as it involves the signal of both single detectors. The $\mathrm{NO}_{2}$ calibrations of the detectors with external cylinders made before and after the flights were insufficient to monitor potential in- flight variations in the detectors sensitivity.

To overcome these issues a mathematical method based on the ozone concentrations measured simultaneously on board the DLR-Falcon was developed for the interpretation of results (see Sect. 4.1). This procedure enables the monitoring of potential changes in the sensitivity of the detectors and the calculation of effective calibration parameters.

\subsection{Calculation of $\mathrm{RO}_{2}^{*}$ mixing ratios during the AMMA flights}

Provided that the signal measured in the background is essentially defined by the ambient $\mathrm{O}_{3}$ converted to $\mathrm{NO}_{2}$ by its reaction with the added $\mathrm{NO}$ and that the response of the luminol detector remains linear (i.e., $\mathrm{NO}_{2}=a X+b$ ), the sensitivity of each detector for each single point $k$ during a selected time interval can be calculated.

Thus, the sensitivity of one of the detectors $S_{\mathrm{D} 1}=1 / a_{\mathrm{D} 1}$ at a time $k$ can be calculated from two consecutive $\mathrm{O}_{3}$ measurements at the time $k$ and $k+1,\left(\left[\mathrm{O}_{3}\right]_{(k i)}\right.$ written as $\mathrm{O}_{3(k i)}$ for simplicity): 


$$
\begin{aligned}
& S_{\mathrm{D} 1}=\frac{X_{(k)}-X_{(k+1)}}{\mathrm{O}_{3(k)}-\mathrm{O}_{3(k+1)}} \\
& \mathrm{O}_{3(k)}-\mathrm{O}_{3(k+1)}=\left(a_{\mathrm{D} 1} \cdot X_{(k)}+b_{1}\right)-\left(a_{\mathrm{D} 1} \cdot X_{(k+1)}+b_{1}\right) \\
& =a_{\mathrm{D} 1} \cdot\left(X_{(k)}-X_{(k+1)}\right) \\
& a_{\mathrm{D} 1}=\frac{\mathrm{O}_{3(k)}-\mathrm{O}_{3(k+1)}}{X_{(k)}-X_{(k+1)}} ;
\end{aligned}
$$

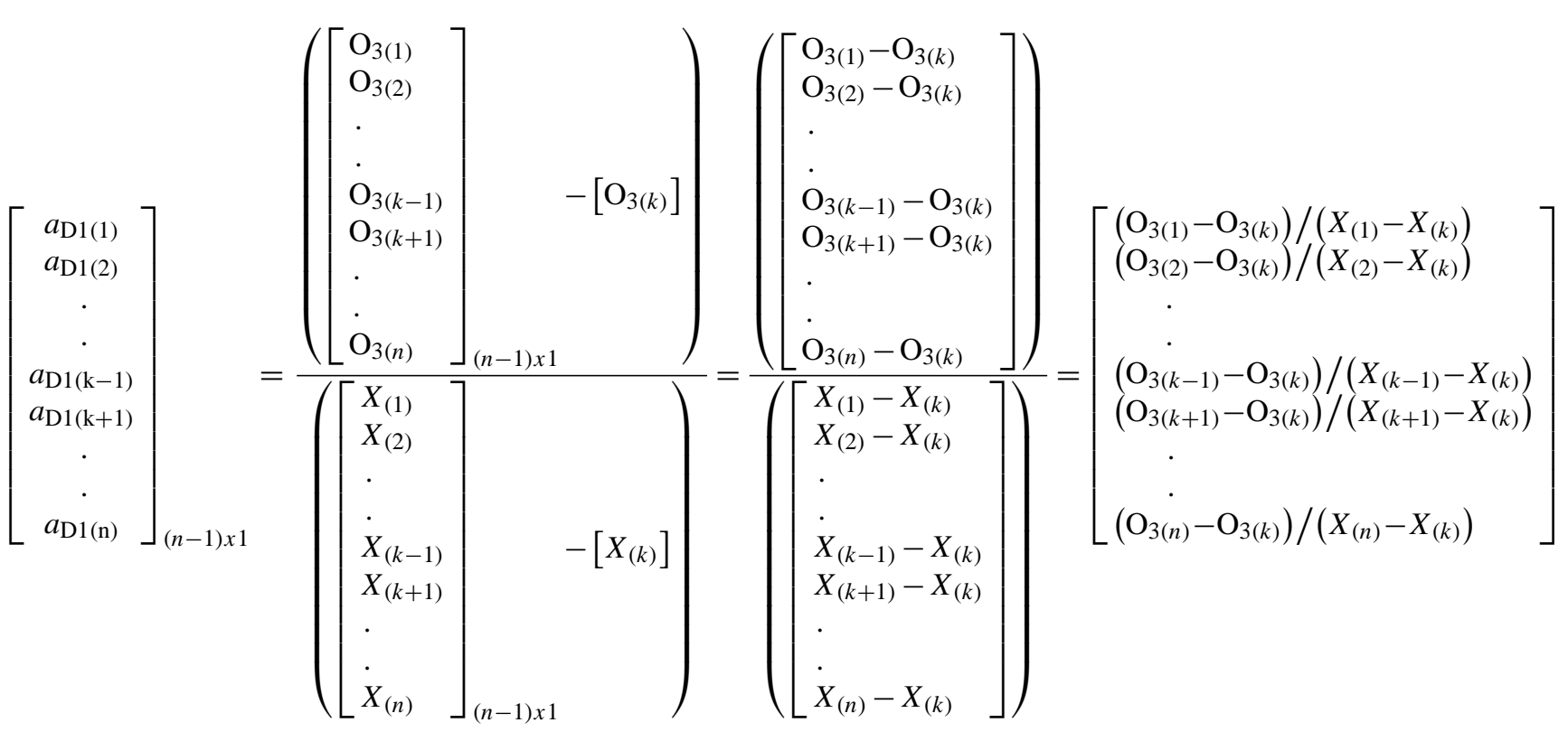

Thus, a sensitivity array is attributed to each $\mathrm{NO}_{2}$ measuring point of a luminol detector, $S_{\mathrm{D} 1(k)}^{*}=1 / a_{\mathrm{D} 1(k)}^{*}$ being the mean value of the sensitivity of the detector at one point for a selected time interval.

$$
a_{\mathrm{D} 1(k)}^{*}=\text { mean }\left(\left[\begin{array}{l}
a_{\mathrm{D} 1(1)} \\
a_{\mathrm{D} 1(2)} \\
\cdot \\
a_{\mathrm{D} 1(k-1)} \\
a_{\mathrm{D} 1(k+1)} \\
\cdot \\
a_{\mathrm{D} 1(n)}
\end{array}\right]_{(n-1) x 1}\right)
$$

Conversely, the value $b$ can be calculated for each measurement point as:
$\left(\left[\begin{array}{l}\mathrm{O}_{3(1)} \\ \mathrm{O}_{3(2)} \\ \cdot \\ \mathrm{O}_{3(k)} \\ \mathrm{O}_{3(k+1)} \\ \cdot \\ \mathrm{O}_{3(n)}\end{array}\right]_{n x 1}\right)-\left(\left[\begin{array}{l}a_{\mathrm{D} 1(1)}^{*} * X_{\mathrm{D} 1(1)} \\ a_{\mathrm{D} 1(2)}^{*} * X_{\mathrm{D} 1(2)} \\ \cdot \\ a_{\mathrm{D} 1(k)}^{*} * X_{(k)} \\ a_{\mathrm{D} 1(k+1)}^{*} * X_{(k+1)} \\ \cdot \\ a_{\mathrm{D} 1(n)}^{*} * X_{(n)}\end{array}\right]_{n x 1}\right)=\left[\begin{array}{l}b_{\mathrm{D} 1(1)}^{*} \\ b_{\mathrm{D} 1(2)}^{*} \\ \cdot \\ b_{\mathrm{D} 1(k)}^{*} \\ b_{\mathrm{D} 1(k+1)} \\ \cdot \\ b_{\mathrm{D} 1(n)}^{*}\end{array}\right]_{n x 1}$

Therefore, a value of $a_{\mathrm{D} 1}^{*}$ and a $b$ value are assigned to each detector signal. The variability of these parameters indicates the sensitivity variations of the detectors.

The values obtained are further used to calculate the mixing ratios of the peroxy radicals at a time $k$ within each time period selected, which normally corresponds with a flight pressure level:

$\begin{aligned} {\left[\mathrm{RO}_{2}^{*}\right]_{\text {reactor1 }} } & =\frac{\Delta \mathrm{NO}_{2}}{\mathrm{eCL}_{\text {reactor1 }}} \Rightarrow \frac{A_{\text {Det1 }} \cdot X_{1(k)}-A_{\text {Det2 }} \cdot X_{2(k)}+\left(B_{\text {Det1 }}-B_{\text {Det2 }}\right)}{\mathrm{eCL}_{\text {reactor1 }}} \\ {\left[\mathrm{RO}_{2}^{*}\right]_{\text {reactor2 }} } & =\frac{\Delta \mathrm{NO}_{2}}{\mathrm{eCL}_{\text {reactor2 }}} \Rightarrow \frac{A_{\text {Det2 } 2} \cdot X_{2(k)}-A_{\text {Det1 } 1} \cdot X_{1(k)}+\left(B_{\text {Det2 }}-B_{\text {Det1 } 1}\right)}{\mathrm{eCL}_{\text {reactor2 }}}\end{aligned}$ 

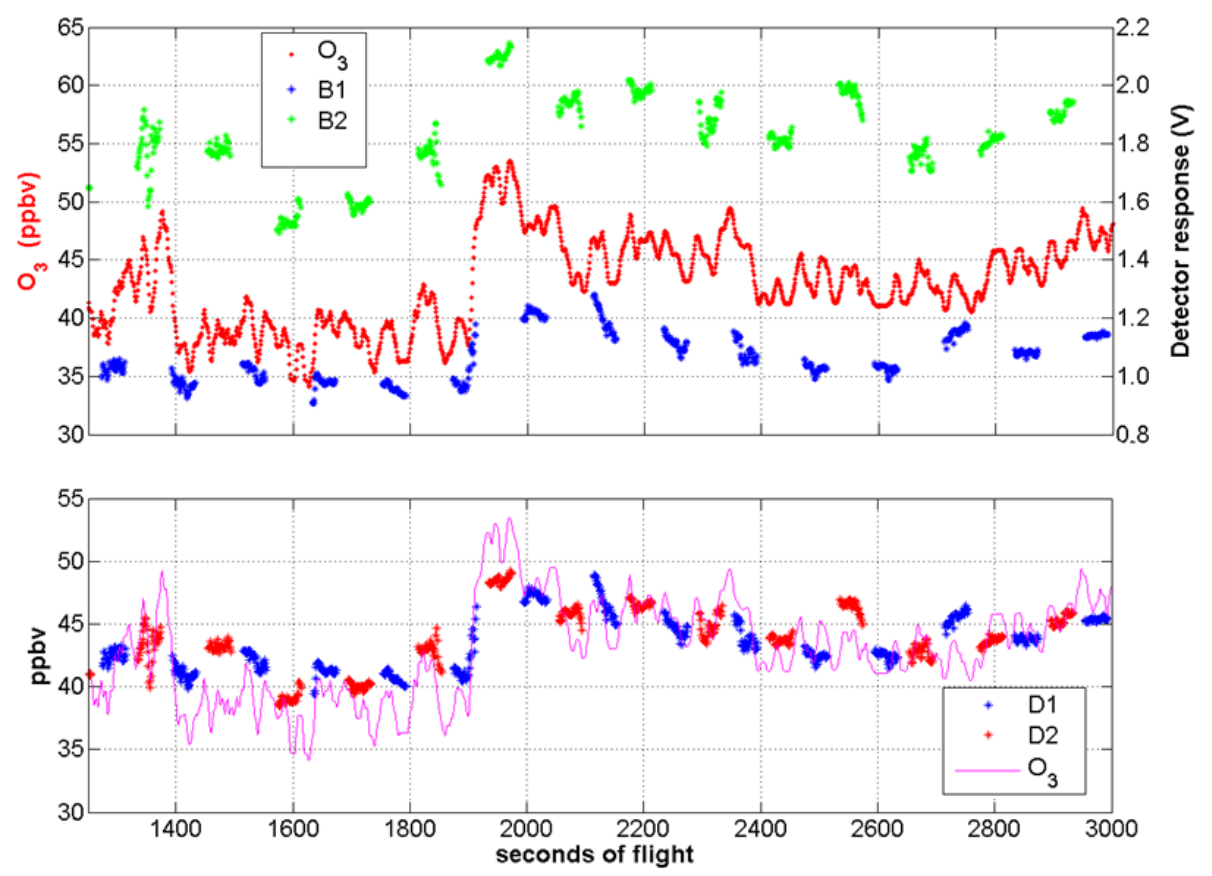

Fig. 12. Example of calculation of effective calibration parameters on the basis of $\mathrm{O}_{3}$ DLR-Falcon measurements at $330 \mathrm{mbar}$ on the 13 August 2006 (900 data points) (a) comparison between $\left[\mathrm{O}_{3}\right]$ in ppbv and background volt signals of the luminol detectors (B1 and $\mathrm{B} 2$, respectively), (b) D1 and D2 detector signals in ppbv calculated with the obtained calibration parameters $\left(A_{\operatorname{Det} 1}=28.2 \pm 4.5 ; A_{\text {Det2 }}=16.8 \pm 3.1\right.$; $\left.B_{\text {Det } 1}=16.9 \pm 1.9 ; B_{\text {Det2 }}=14.3 \pm 1.5\right)$.

where the corresponding eCL are determined in the lab and:

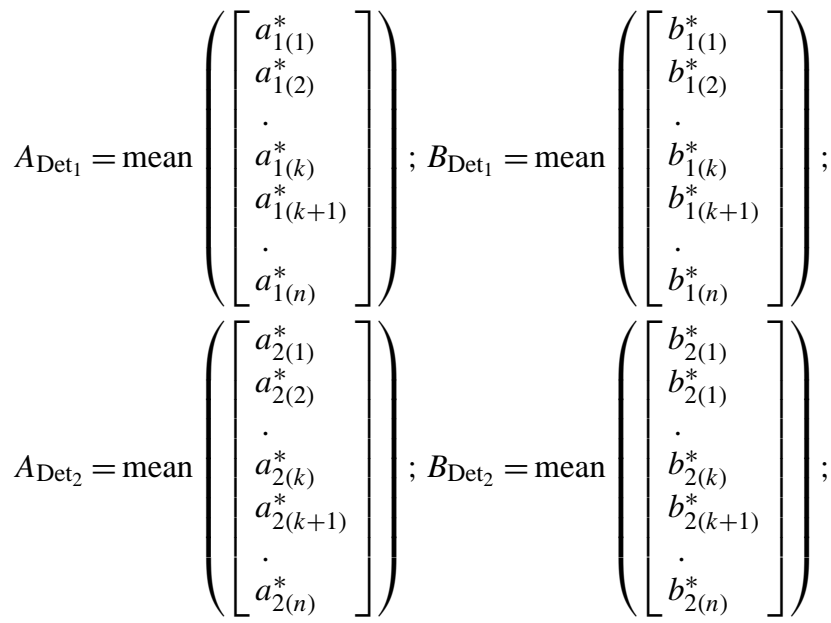

The application of the calculation procedure is exemplary shown in Fig. 12. These measurements were taken at 330 mbar during the flight on the 13 August 2006. In Fig. $12 \mathrm{a}$ the $\left[\mathrm{O}_{3}\right]$ in ppbv is compared to the raw background signal of the luminol detectors in volts. Despite the offset of the signals, the temporal evolution agrees very reasonably as expected. According to the procedure described above, the effective calibration parameters are calculated $\left(A_{\text {Det } 1}=28.2 \pm 4.5 ; A_{\text {Det } 2}=16.8 \pm 3.1 ; B_{\text {Det } 1}=16.9 \pm 1.9\right.$;
$\left.B_{\text {Det } 2}=14.3 \pm 1.5\right)$ and used to obtain the mixing ratios depicted in Fig. 12b.

This method might be subject to a certain error in the case of malfunction of the $\mathrm{O}_{3}$ instrument and/or sudden variations of background ambient gases other than $\mathrm{O}_{3}$ oxidising $\mathrm{NO}$ or providing directly $\mathrm{NO}_{2}$ to the DUALER. However, the variations in $\mathrm{NO}$ and $\mathrm{NO}_{2}$ of the air masses within the periods selected for analysis do not indicate any significant contribution of any potential interference. Within AMMA the $A_{\text {Deti }}$ parameters obtained from the $\mathrm{O}_{3}$ in-flight validation generally varied between 15 and 35 with $15-30 \%$ relative accuracy, in reasonable agreement with the $a$ parameters obtained in the laboratory, which varied between 10 and 30 with $3 \%$ accuracy.

\subsection{Error analysis and detection limit}

The calculation of the error associated with the $\mathrm{RO}_{2}^{*}$ mixing ratios must take into account the contribution of the following sources of uncertainty:

1. $\mathrm{NO}_{2}$ detector sensitivity. This is determined by the $\mathrm{NO}_{2}$ calibrations with cylinders of known concentration (see Sect. 2.2) and the reproducibility is within $99 \%$ for laboratory measurements taken with the same filter and under the same pressure conditions. By using the procedure described in Sect. 4.1, the relative accuracy of the 

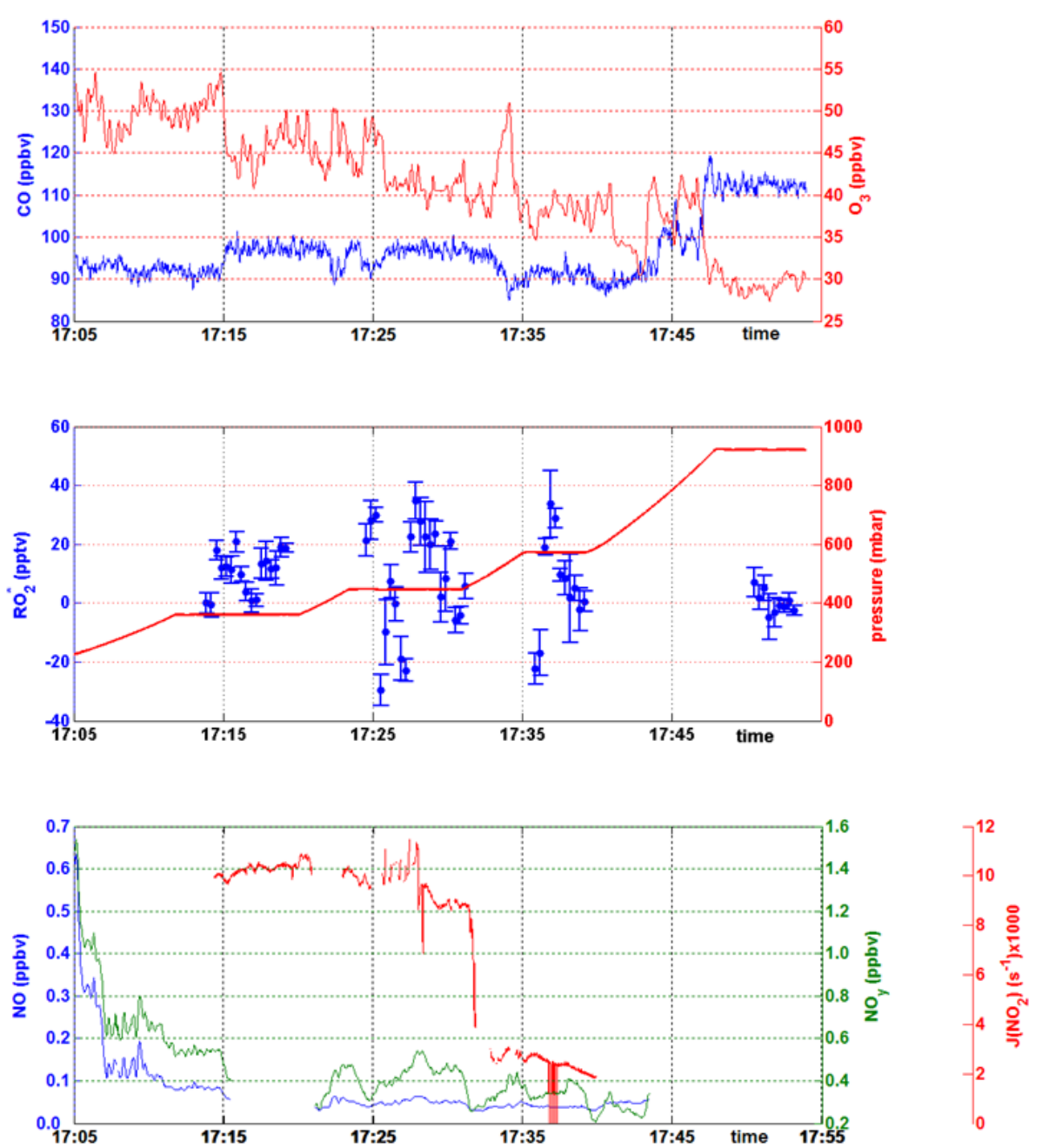

Fig. 13. Mixing ratios measured on the 11 August 2006 within a vertical profile taken between 360 and 960 mbar. The [RO 2 error bars represent the statistical error of the $20 \mathrm{~s}$ averages. The total $\left[\mathrm{RO}_{2}^{*}\right]$ error remains below $45 \%$ (see text).

$\mathrm{NO}_{2}$ airborne measurements remains between $20 \%$ and $35 \%$.

2. CL determination. The effective $C L$ is determined in the laboratory for a particular measurement pressure with a $15 \%$ standard deviation. Potential in-flight losses of radicals before reaching the addition point in the reactor can only be estimated. These might be of significance in the presence of clouds or aerosols

3. Radical partitioning in the air sampled. The presence of peroxy radicals other than $\mathrm{HO}_{2}$ leads to an overestimation of the $\left[\mathrm{RO}_{2}^{*}\right]$ which most likely remains between 8 and $14 \%$ for the most likely expected $\mathrm{HO}_{2} / \mathrm{CH}_{3} \mathrm{O}_{2}$ ratio as stated in Sect. 3.3. There is no information available about the relative distribution of peroxy radicals during AMMA except for the radical intercomparison exercise (Andrés Hernández et al., 2010) where the $\mathrm{HO}_{2} / \mathrm{RO}_{2}$ ratio remained close to $1: 1$. Complementary modeling re- sults indicated that $\mathrm{CH}_{3} \mathrm{O}_{2}$ represents $90 \%$ of the alkyl peroxy radicals present (Stone et al., 2010).

The detection limit of the $\mathrm{NO}_{2}$ detector is calculated as 3 times the standard deviation of $20 \mathrm{~s}$ signal averages at each calibration point made at $200 \mathrm{mbar}$ under laboratory conditions. This leads to a value of $0.13 \pm 0.05 \mathrm{ppb} \mathrm{NO}_{2}$. As the $\mathrm{eCL}=45 \pm 7$ at $200 \mathrm{mbar}$, the $\mathrm{RO}_{2}^{*}$ detection limit is $3 \pm 2 \mathrm{pptv}$ for $20 \mathrm{~s}$ time resolution.

During AMMA, a total of 8 DLR-Falcon flights were conducted from Ouagadougou in Burkina Faso $\left(12.15^{\circ} \mathrm{N}\right.$ $1.30^{\circ} \mathrm{W}$ ) in the period from 1-18 August 2006. An overview of the aircraft campaign and details of the flights are described in Reeves et al. (2010). The results of the radical intercomparison exercise during the flight on the $16 \mathrm{Au}$ gust 2006 are analysed elsewhere (Andrés-Hernández et al., 2010).

The total $\left[\mathrm{RO}_{2}^{*}\right]$ error calculated from the propagation of the errors above remains between 25 and $45 \%$ within 

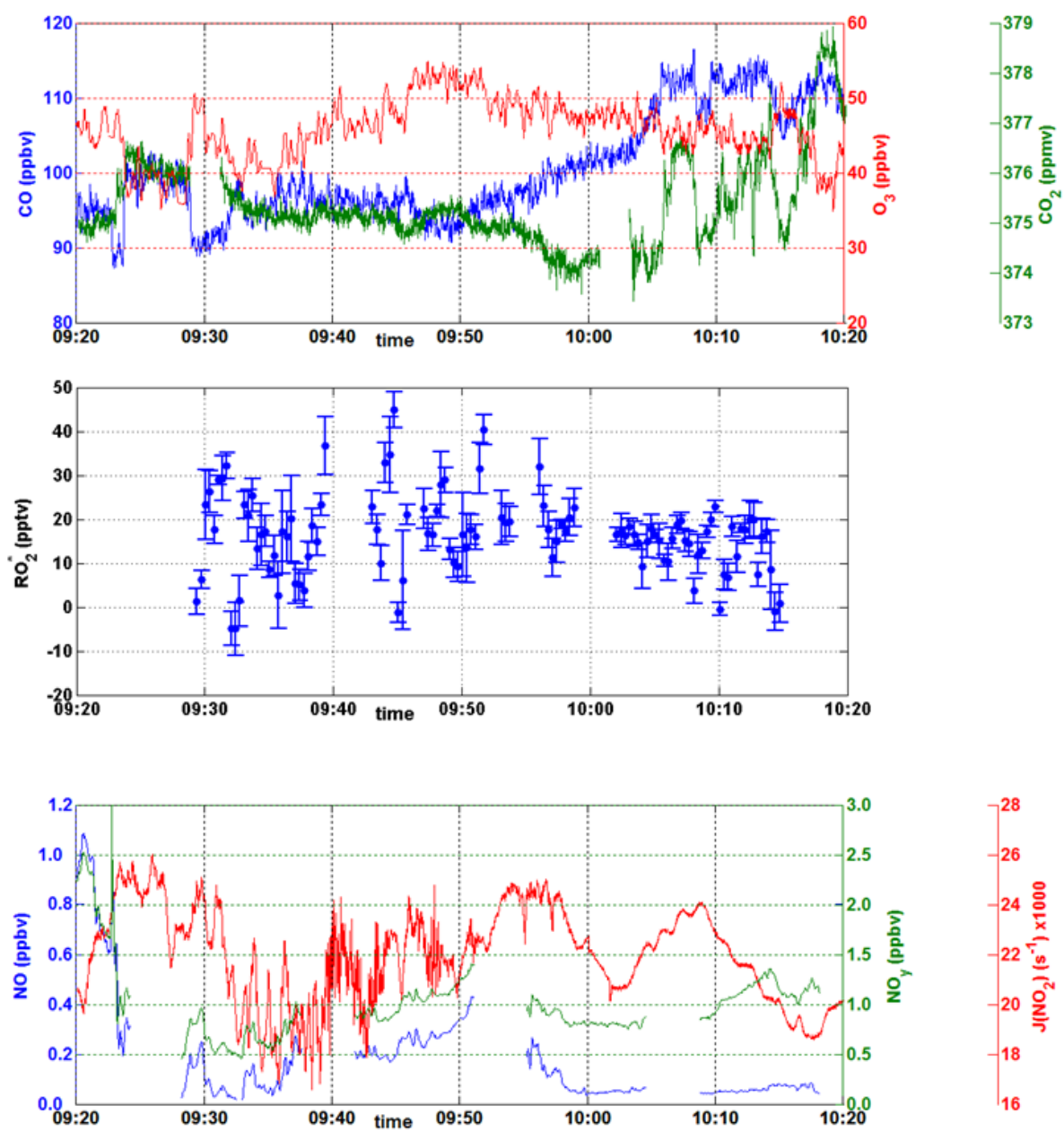

Fig. 14. Mixing ratios measured on the 4 August 2006 at 315 mbar. The $\left[\mathrm{RO}_{2}^{*}\right]$ error bars represent the statistical error of the $20 \mathrm{~s}$ averages. The total $\left[\mathrm{RO}_{2}^{*}\right]$ error remains around $25 \%$ (see text).

AMMA, depending on the flight conditions and the stability of the measurement signals for any particular measurement interval.

\subsection{Application to AMMA measurements}

The analysis of AMMA peroxy radical measurements during episodes of intense convection and biomass burning is presented elsewhere (Andrés-Hernández et al., 2009). The $\mathrm{RO}_{2}^{*}$ data selected in Figs. 13 and 14 illustrate AMMA measurement situations associated with errors of different origin and magnitude.

On the 11 August 2006 a vertical profile from 360 mbar was taken over Ouagadougou before landing. The $\left[\mathrm{RO}_{2}^{*}\right]$ are quite variable at the different pressure levels measured. In the first two levels at 360 and $450 \mathrm{mbar}$, total odd nitrogen $\left(\mathrm{NO}_{\mathrm{y}}\right), \mathrm{O}_{3}$ and $\mathrm{CO}$ change abruptly indicating the chemical inhomogeneity of the air mass sampled. This situation disturbs the local chemistry and leads to short term variations in the background concentrations which can then result in the calculation of $\mathrm{RO}_{2}^{*}$ negative mixing ratios. Although chemically meaningless, these negative values are not removed from the data set as they are not caused by instrument failures and provide useful information about radical variability and instrument response in such a rapid changing environment. The analysis of data is however based on periods of stable conditions.

At 570 mbar the longer lived species $\mathrm{CO}$ and $\mathrm{O}_{3}$ remain fairly constant whereas $\mathrm{NO}_{\mathrm{y}}$ variations seem to define the $\mathrm{RO}_{2}^{*}$ variability. Close to the surface at the highest pressure level, the $\mathrm{RO}_{2}^{*}$ mixing ratios are low and close to the detection limit. The $\left[\mathrm{RO}_{2}^{*}\right]$ error bars in Fig. 13 represent the statistical error of the $20 \mathrm{~s}$ averages. The total error all over the vertical profile remains between 40 and $45 \%$.

Figure 14 illustrate the variations of the $\mathrm{RO}_{2}^{*}$ mixing ratios measured on the 4 August 2006 at 315 mbar. In this case, the outflow of a mesoscale convective system was sampled from 09:00 to 10:00 $\mathrm{h}$. The measurement period is characterised by high $\mathrm{NO}, \mathrm{NO}_{\mathrm{y}}$ and $\mathrm{RO}_{2}^{*}$ variability which is partly 
Table A1. Reactions used in the chemical box model. The rate coefficients are in units of $\mathrm{cm}^{3}$ molecule $\mathrm{s}^{-1}$ except for the first order heterogeneous wall loss of $\mathrm{HO}_{2}$ (based on the experimental data of this work) and the unimolecular decomposition of peroxynitric acid $\left(\mathrm{HO}_{2} \mathrm{NO}_{2}\right)$ which are in $\mathrm{s}^{-1}$.

\begin{tabular}{|c|c|c|c|c|c|}
\hline \multirow[t]{2}{*}{ Reaction } & \multicolumn{2}{|c|}{$\begin{array}{c}\text { Low pressure limit } \\
k_{0}(T)=k_{0}^{300}(T / 300)^{-n}\end{array}$} & \multicolumn{2}{|c|}{$\begin{array}{c}\text { High-pressure limit } \\
k_{\infty}(T)=k_{\infty}^{300}(T / 300)^{-m}\end{array}$} & \multirow{2}{*}{$\begin{array}{l}\text { Rate constants } \\
\text { for bimolecular } \\
\text { reactions at } 298 \mathrm{~K}\end{array}$} \\
\hline & $k_{0}^{300}$ & $n$ & $k_{\infty}^{300}$ & $m$ & \\
\hline $\mathrm{NO}+\mathrm{OH} \stackrel{\mathrm{M}}{\longrightarrow} \mathrm{HONO}$ & $7.1 \mathrm{E}-31$ & 2.6 & $3.6 \mathrm{E}-11$ & 0.1 & \\
\hline $\mathrm{NO}_{2}+\mathrm{OH} \stackrel{\mathrm{M}}{\longrightarrow} \mathrm{HONO}_{2}$ & $2 \mathrm{E}-30$ & 3 & $2.5 \mathrm{E}-11$ & 0 & \\
\hline $\mathrm{NO}_{2}+\mathrm{HO}_{2} \stackrel{\mathrm{M}}{\longrightarrow} \mathrm{HO}_{2} \mathrm{NO}_{2}$ & $1.8 \mathrm{E}-31$ & 3.2 & $4.7 \mathrm{E}-12$ & 1.4 & \\
\hline $\mathrm{HO}_{2} \mathrm{NO}_{2} \stackrel{\mathrm{M}}{\longrightarrow} \mathrm{NO}_{2}+\mathrm{HO}_{2}$ & \multicolumn{4}{|c|}{$k=k_{\mathrm{NO}_{2}+\mathrm{HO}_{2}} /(2.1 \mathrm{E}-27 \cdot \exp (10900 T))$} & \\
\hline $\mathrm{OH}+\mathrm{OH} \stackrel{\mathrm{M}}{\longrightarrow} \mathrm{H}_{2} \mathrm{O}_{2}$ & $6.9 \mathrm{E}-31$ & 1 & $2.6 \mathrm{E}-11$ & 0 & \\
\hline $\begin{array}{l}\mathrm{CO}+\mathrm{OH} \stackrel{\mathrm{O}_{2}}{\longrightarrow} \mathrm{CO}_{2}+\mathrm{HO}_{2} \\
\mathrm{NO}+\mathrm{HO}_{2} \rightarrow \mathrm{OH}+\mathrm{NO}_{2}\end{array}$ & & & & & $\begin{array}{c}(1.5 \mathrm{E} 13) \cdot(1+0.6 P) \\
8.1 \mathrm{E}-12\end{array}$ \\
\hline $\mathrm{HO}_{2}+\mathrm{HO}_{2} \stackrel{\mathrm{M}}{\longrightarrow} \mathrm{H}_{2} \mathrm{O}_{2}+\mathrm{O}_{2}$ & & & & & $(4.9 \mathrm{E} 32) \cdot[\mathrm{M}]$ \\
\hline $\mathrm{OH}+\mathrm{HONO} \rightarrow \mathrm{H}_{2} \mathrm{O}+\mathrm{NO}_{2}$ & & & & & $4.5 \mathrm{E}-12$ \\
\hline $\mathrm{H}_{2} \mathrm{O}_{2}+\mathrm{OH} \rightarrow \mathrm{HO}_{2}+\mathrm{H}_{2} \mathrm{O}$ & & & & & $1.7 \mathrm{E}-12$ \\
\hline $\mathrm{HO}_{2}+\mathrm{OH} \rightarrow \mathrm{O}_{2}+\mathrm{H}_{2} \mathrm{O}$ & & & & & $1.1 \mathrm{E}-12$ \\
\hline $\mathrm{CH}_{3} \mathrm{O}_{2}+\mathrm{HO}_{2} \rightarrow \mathrm{CH}_{3} \mathrm{OOH}+\mathrm{O}_{2}$ & & & & & $5.2 \mathrm{E}-12$ \\
\hline $\mathrm{CH}_{3} \mathrm{O}_{2}+\mathrm{NO} \rightarrow \mathrm{CH}_{3} \mathrm{O}+\mathrm{NO}_{2}$ & & & & & $7.7 \mathrm{E}-12$ \\
\hline $\mathrm{CH}_{3} \mathrm{O}+\mathrm{O}_{2} \rightarrow \mathrm{CH}_{2} \mathrm{O}+\mathrm{HO}_{2}$ & & & & & $1.9 \mathrm{E}-15$ \\
\hline $\begin{array}{l}\mathrm{CH}_{3} \mathrm{O}+\mathrm{NO} \stackrel{\mathrm{M}}{\longrightarrow} \mathrm{CH}_{3} \mathrm{ONO} \\
\mathrm{HO}_{2}+\text { walls } \rightarrow \text { non-radical products }\end{array}$ & $1.4 \mathrm{E}-29$ & 3.8 & $3.6 \mathrm{E}-11$ & 0.6 & 1.5 (this work) \\
\hline
\end{tabular}

associated with the presence of clouds and fresh emissions (Andrés-Hernández et al., 2009). In spite of the complex local chemistry, the generally smooth $\mathrm{O}_{3}$ variations minimise the error associated with the $\mathrm{RO}_{2}^{*}$ validation algorithm presented in Sect. 4.1 and the total $\left[\mathrm{RO}_{2}^{*}\right]$ error remains around $37 \%$.

\section{Summary and conclusions}

A DUALER instrument based on the chemical amplification technique is proposed for the airborne measurement of peroxy radicals. Due to the fluctuations in signal and sensitivity of the luminol detectors with the pressure, the system is kept at constant pressure during the measurement.

The pressure regulation at a pre-reactor nozzle, though optimising the detector output and stabilising the reactor chain length, introduces turbulences which enhance radical wall losses prior to chemical conversion and amplification. The chain length determined experimentally is therefore an effective chain length (eCL), resulting from the amplification of the radicals reaching the gas addition point at the reactors. The losses at the pre-reactor nozzle are mainly wall losses. The eCL varies with $\Delta P=P_{\text {ambient }}-P_{\text {DUALER }}$ indicating the effect of turbulences and retention time in the wall losses at the pre-reactor nozzle. Each DUALER instrument must therefore be thoroughly characterised prior to any deployment in an airborne platform. Knowledge of the reten- tion time in the pre-reactor nozzle enables the calculation of the eCL for different $\Delta P$.

According to the laboratory characterisation of the IUPUB DUALER regarding the signal to noise ratio, the stability of luminol flows in the $\mathrm{NO}_{2}$ detectors, the eCL, and the $\mathrm{CO}$ consumption, the performance of the instrument during airborne measurements is expected to be at the best for $\Delta P$ around 500 mbar. The actual DUALER configuration is not suitable for system pressures below $200 \mathrm{mbar}$ and this restricts the measurement to ambient pressures above 270 mbar.

The response of the instrument for different peroxy radicals was also investigated. As expected, higher eCL were experimentally determined for $\mathrm{CH}_{3} \mathrm{O}_{2}$ than for $\mathrm{HO}_{2}$. This is interpreted to be the result of lower wall losses of $\mathrm{CH}_{3} \mathrm{O}_{2}$ in the pre-reactor nozzle. These experimental results were utilised to simulate the eCL for different mixtures of peroxy radicals. Using a common eCL for the determination of $\left[\mathrm{RO}_{2}^{*}\right]$ in ambient samples is subject to an additional error which most likely remains between 8 and $14 \%$ depending on the $\left[\mathrm{HO}_{2}\right] /\left[\mathrm{CH}_{3} \mathrm{O}_{2}\right]$ ratio.

The IUP-UB DUALER was successfully deployed during the AMMA measurement campaign in West Africa in 2006. In order to cover most of the measurement conditions, the pressure of the system was kept at 200 mbar. $\left[\mathrm{RO}_{2}^{*}\right]$ between 5 and 60 pptv were measured in air masses of different photochemical characteristics (Andrés-Hernández et al., 2009). 
A validation procedure based on simultaneous $\mathrm{O}_{3}$ measurements onboard is proposed to monitor and correct variations in detector sensitivity during the flight. In such a manner, the total error of the $\mathrm{RO}_{2}^{*}$ mixing ratios vary between 25 and $45 \%$ depending on the detector performance and flight conditions.

\section{Appendix A}

\section{Box model}

A chemical box model based on the fourth order RungeKutta numerical analysis method by programming with Matlab 7.0 was developed for the simulations within this work. The procedure is presented more in detail in Kartal (2009). The reactions used are summarized in Table A1. All reaction rates except for the heterogeneous $\mathrm{HO}_{2}$ wall loss are according to JPL-publication JPL 06-2 (Sander et al., 2006).

Acknowledgements. The authors would like to thank the mechanical workshop at the Institute of Environmental Physics of the University of Bremen for the enormous support and excellent contribution in the construction of the DUALER and calibration setups.

Based on a French initiative, AMMA was built by an international scientific group and is currently funded by a large number of agencies. It has been the beneficiary of a major financial contribution from the European Community Sixth Framework Research Programme. Detail information on scientific coordination and funding is available on the AMMA International web site at www.amma-eu.org.

Edited by: C. Reeves

\section{References}

Andrés-Hernández, M. D., Burkert, J., Reichert, L., Stöbener, D., Meyer-Arnek J., Burrows, J. P., Dickerson, R. R., and Doddridge, B.: Marine boundary layer peroxy radical chemistry during the AEROSOLS99 campaign: measurements and analysis, J. Geophys. Res., 106(D18), 20833-20846, 2001.

Andrés-Hernández, M. D., Kartal, D., Reichert, L., Burrows, J. P., Meyer Arnek, J., Lichtenstern, M., Stock, P., and Schlager, H.: Peroxy radical observations over West Africa during AMMA 2006: photochemical activity in the outflow of convective systems, Atmos. Chem. Phys., 9, 3681-3695, 2009, http://www.atmos-chem-phys.net/9/3681/2009/.

Andrés-Hernández, M.D., Stone, D., Brookes, D.M., Commane, R., et al.: Peroxy radical partitioning during the AMMA radical intercomparison exercise, Atmos. Chem. Phys. Discuss., in review, 2010.

Burkert, J., Behmann, T., Andrés-Hernández, M. D., Weißenmayer, M., Perner, D., and Burrows, J. P.: Measurements of peroxy radicals in a forested area in Portugal, Chemosphere, 3(3), 33273338, 2001a.

Burkert, J., Andrés-Hernández, M. D., Stöbener, D., Burrows, J. P., Weissenmayer, M., and Kraus, A.: Peroxy radical and related trace gas measurements in the boundary layer above the Atlantic Ocean, J. Geophys. Res., 106(6), 5457-5477, 2001 b.
Burkert, J., Andrés-Hernández, M. D., Reichert, L., Stöbener, D., Meyer-Arnek J., and Burrows, J. P., Mühle, J., Zahn, A., Carsey, T., Dickerson, R. R., and Doddridge, B.: Trace gas and radical behaviour in the marine boundary layer during INDOEX 1999, J. Geophys. Res., 108(D8), 8000, doi:10.1029/2002JD002790, 2003.

Carslaw, N., Creasey, D. J., Heard, D. E., Lewis, A. C., McQuaid, J. B., Pilling, M. J.,,Monks, P. S., Bandy B. J., and Penkett, S. A.: Modelling $\mathrm{OH}, \mathrm{HO}_{2}$, and $\mathrm{RO}_{2}$ in the marine boundary layer: 1 . Model construction and comparison with field measurements, J. Geophys. Res., 104(D23), 30241-30255, 1999.

Cantrell, C. A. and Stedman, D. H.: A possible technique for the measurement of atmospheric peroxy radicals, Geophys. Res. Lett., 9, 846-849, 1982.

Cantrell, C. A., Shetter, R. E., Lind, J. A., et al.: An Improved Chemical Amplifier Technique for Peroxy Radical Measurements, J. Geophys. Res., 98(D2), 2897-2909, 1993.

Cantrell, C. A., Shetter, R. E., Gilpin, T. M., Calvert, J. G., Eisele, F. L., and Tanner, D. J.: Peroxy radical concentrations measured and calculated from trace gas measurements in the Mauna Loa Photochemistry Experiment 2, J. Geophys. Res., 101, 1465314664, 1996a.

Cantrell, C. A., Shetter, R. E., and Calvert, J. G.: Dual-Inlet chemical amplifier for atmospheric peroxy radical measurements, Analyt. Chemistry, 68, 4194-4199, 1996 b.

Cantrell, C. A., Zimmer, A., and Tyndall, G. S.: Absorption cross sections for water vapour from 183 to $193 \mathrm{~nm}$, Geophys. Res. Lett., 24, 2195-2198, 1997.

Cantrell, C. A., Edwards, G. D., Stephens, S., Mauldin, L., Kosciuch, E., Zondlo, M., Eisele, F.,: Peroxy radical observations using chemical ionization mass spectrometry during TOPSE, J. Geophys. Res., 108(D6), 8371, doi:10.1029/2002JD002715, 2003a.

Cantrell, C. A., Edwards, G. D., Stephens, S., Mauldin, L., et al.: Peroxy radical behaviour during the Transport and Chemical Evolution over the Pacific (TRACE-P) campaign as measured aboard the NASA P-3B aircraft, J. Geophys. Res., 108(D20), 8797, doi:10.1029/2003JD003674, 2003b.

Clemitshaw, K., Carpenter, L., Penkett, S., and Jenkin, M.: A calibrated peroxy radical chemical amplifier for ground-based tropospheric measurements, J. Geophys. Res., 102(D21), 2540525416, 1997.

Clemitshaw, K. C.: A review of instrumentation and measurement techniques for field studies of gas-phase tropospheric chemistry, Crit. Rev. Env. Sci. Technol., 34, 1-108, 2004.

Creasey, D., Heard, D. E., and Lee, J. D.: Absorption cross-section measurements of water vapour and oxygen at $185 \mathrm{~nm}$. Implications for the calibration of field instruments to measure $\mathrm{OH}$, $\mathrm{HO}_{2}$ and $\mathrm{RO}_{2}$ radicals, Geophys. Res. Lett., 27(11), 1651-1654, 2000.

Edwards, G. D., Cantrell, C. A., Stephens, S., et al.: Chemical Ionization Mass Spectrometer Instrument for the measurement of tropospheric $\mathrm{HO}_{2}$ and $\mathrm{RO}_{2}$, Anal. Chem., 75, 5317-5327, 2003.

Fleming, Z. L., Monks, P. S., Rickard, A. R., Heard, D. E., Bloss, W. J., Seakins, P. W., Still, T. J., Sommariva, R., Pilling, M. J., Morgan, R., Green, T. J., Brough, N., Mills, G. P., Penkett, S. A., Lewis, A. C., Lee, J. D., Saiz-Lopez, A., and Plane, J. M. C.: Peroxy radical chemistry and the control of ozone photochemistry at Mace Head, Ireland during the summer of 2002, Atmos. 
Chem. Phys., 6, 2193-2214, 2006a,

http://www.atmos-chem-phys.net/6/2193/2006/.

Fleming, Z. L., Monks, P. S., Rickard, A. R., Bandy, B. J., Brough, N., Green, T. J., Reeves, C. E., and Penkett, S. A.: Seasonal dependence of peroxy radical concentrations at a Northern hemisphere marine boundary layer site during summer and winter: evidence for radical activity in winter, Atmos. Chem. Phys., 6, 5415-5433, 2006b, http://www.atmos-chem-phys.net/6/5415/2006/.

Fuchs, H., Brauers, T., Häseler, R., Holland, F., Mihelcic, D., Müsgen, P., Rohrer, F., Wegener, R., and Hofzumahaus, A.: Intercomparison of peroxy radical measurements obtained at atmospheric conditions by laser-induced fluorescence and electron spin resonance spectroscopy, Atmos. Meas. Tech., 2, 55-64, 2009,

http://www.atmos-meas-tech.net/2/55/2009/.

Green, T. J., Brough, N., Reeves, C. E., Edwards, G. D., Monks, P. S., and Penkett, S. A.: Airborne measurements of peroxy radicals using the PERCA technique, J. Environ.Monitor., 5, 75-83, 2003.

Green, T. J., Reeves, C. E., Fleming, Z. L., Brough, N., Rickard, R. A., Bandy, B. J., Monks, P. S., and Penkett, S. A.: An improved dual channel PERCA instrument for atmospheric measurements of peroxy radicals, J. Environ. Monitor., 8, 530-536, doi:10.1039/b514630e, 2006.

Hastie, D. R., Weißenmayer, M., Burrows, J. P., and Harris, G. W.: Calibrated chemical amplifier for atmospheric ROx measurements, Anal. Chem., 63, 2048-2057, 1991.

Hayman, G. D.: Numerical Model of the Calibration Source of a PERCA Instrument, AEA Technology Report, 2473/20410001/001, issue 1, 1997.

Hofzumahaus, A., Brauers, T., Aschmutat, U., Brandenburger, U., Dorn, H. P., Hausmann, M., Heßling, M., Holland, F., PlassDülmer, C., Sedlacek, M., Weber, M., and Ehhalt, D. H.: Reply Geophys. Res. Lett., 24(23), 3039-3040, 1997.

Kartal, D.: Peroxy radical measurements under controlled conditions and further investigation of pressure dependence of PERCA for airborne measurements, M.S. thesis, University of Bremen, Germany, 2004.

Kartal, D.: Characterization and optimisation of a dual channel PERCA for the investigation of the chemistry of peroxy radicals in the upper troposphere, $\mathrm{PhD}$ thesis, University of Bremen, Germany, 2009.

Lightfoot, P. D., Cox, R. A., Crowley, J. N., Destriau, M., Hayman, G. D., Jenkin, M. E., Moortgat, G. K., and Zabel, F.: Organic Peroxy Radicals, kinetics, spectroscopy and tropospheric chemistry, CEC Air Pollution Research Report 40, 1993.

Mihelcic, D., Volz-Thomas, A., Pätz, H. W., Kley, D., and Mihelcic, M.: Numerical analysis of ESR spectra from atmospheric samples, J. Atmos. Chem., 11, 271-297, 1990

Mihele, C. M. and Hastie, D. R.: The sensitivity of the radical amplifier to ambient water vapour, Geophys. Res. Lett., 25, 1911-
1913, 1998.

Mihele, C. M., Mozurkewich, M., and Hastie, D. R.: Radical loss in a chain reaction of $\mathrm{CO}$ and $\mathrm{NO}$ in the presence of water: Implications for the radical amplifier and atmospheric chemistry, Intern. J. Chem. Kinetics, 31, 145-152, 1999.

Monks, P. S., Carpenter, L. J., and Penkett, S. A.: Night-time peroxy radical chemistry in the remote marine boundary layer over the Southern ocean, Geophys. Res. Lett., 23(5), 535-538, 1996.

Reeves, C. E., Formenti, P., Afif, C., Ancellet, G., Attie, J.-L., Bechara, J., Borbon, A., Cairo, F., Coe, H., Crumeyrolle, S., Fierli, F., Flamant, C., Gomes, L., Hamburger, T., Lambert, C., Law, K. S., Mari, C., Matsuki, A., Methven, J., Mills, G. P., Minikin, A., Murphy, J. G., Nielsen, J. K., Oram, D. E., Parker, D. J., Richter, A., Schlager, H., Schwarzenboeck, A., and Thouret, V.: Chemical and aerosol characterisation of the troposphere over West Africa during the monsoon period as part of AMMA, Atmos. Chem. Phys. Discuss., 10, 7115-7183, 2010, http://www.atmos-chem-phys-discuss.net/10/7115/2010/.

Reiner, T., Hanke, M., and Arnold, F.: Atmospheric peroxy radical measurements by ion molecule reaction mass-spectrometry: a novel analytical method using amplifying chemical conversion to sulphuric acid, J. Geophys. Res., 102, 1311-1326, 1997.

Reichert, L., Andrés-Hernández, M. D., Stöbener, D., Burkert, J., and Burrows, J. P.: Investigation of the effect of water complexes in the determination of peroxy radical ambient concentrations: implications for the atmosphere, J. Geophys. Res., 108(D1), 4017-4032, 2003.

Sander, S. P., Orkin, V. L., Kurylo, M. J., Golden, D. M., Huie, R. E., Kolb, C. E. , Finlayson-Pitts, B. J., Molina, M. J., Friedl, R. R., Ravishankara, A. R., Moortgat, G. K., Keller-Rudek, H., and Wine, P. H.: Chemical Kinetics and Photochemical Data for Use in Atmospheric Studies Evaluation Number 15, JPL publication 06-2, Jet Propulsion Laboratory, 2006.

Schultz, M., Heitlinger, M., Mihelcic, D., and Volz-Thomas, A.: A calibration source for peroxy radicals with built-in actinometry using $\mathrm{H}_{2} \mathrm{O}$ and $\mathrm{O}_{2}$ photolysis at $185 \mathrm{~nm}$, J. Geophys. Res., 100, 18811-18816, 1995.

Stone, D., Commane, R., Floquet, C. F. A., Ingham, T., et al.: Understanding $\mathrm{HO}_{\mathrm{x}}$ observations over West Africa during AMMA: Box modelling with the MCM, Atmos. Chem. Phys. Discuss., in preparation, 2010.

Volz-Thomas A., Pätz, H.-W., Houben, N., Konrad, S., Mihelcic, D., Klüpfel, T., and Perner, D.: Inorganic trace gases and peroxy radicals during BERLIOZ at Pabstthum: An investigation of the photostationary state of $\mathrm{NO}_{\mathrm{x}}$ and $\mathrm{O}_{3}$, J. Geophys. Res., 108(D4), 8248, doi:10.1029/2001JD001255, 2003.

Zanis, P., Monks, P. S., Green, T. J., Schuepbach, E., Carpenter, L. J., Mills, G. P., Rickard, A. R., and Penkett, S. A.: Seasonal variation of peroxy radicals in the lower free troposphere based on observations from the FREE Tropospheric EXperiments in the Swiss Alps, Geophys. Res. Lett., 30(10), 1497, doi:10.1029/2003GL017122, 2003. 